\title{
The role of residential rooftop photovoltaic in long-term energy and climate scenarios
}

\author{
David E.H.J. Gernaat ${ }^{\text {a,b, }}$, Harmen-Sytze de Boer ${ }^{\mathrm{a}, \mathrm{b}}$, Louise C. Dammeier ${ }^{\mathrm{a}, \mathrm{c}}$, Detlef P. van \\ Vuuren ${ }^{\mathrm{a}, \mathrm{b}}$ \\ ${ }^{a}$ PBL Netherlands Environment Assessment Agency, Bezuidenhoutseweg 30, 2594 AV Den Haag, the Netherlands \\ ${ }^{\mathrm{b}}$ Copernicus Institute of Sustainable Development, Utrecht University, Princetonlaan 8, 3584 CB Utrecht, the Netherlands \\ ${ }^{\mathrm{c}}$ Department of Environmental Science, Radboud University, Heyendaalseweg 135, 6525 AJ Nijmegen, the Netherlands
}

\section{H I G H L I G H T S}

- Rooftop PV key driver in the PV market, thus modelled in IMAGE IAM.

- Global estimated potential 8.3 $\mathrm{PWh} \mathrm{y}^{-1}: 1.5$ times residential electricity demand.

- Scenarios show key role for rooftop PV but regional characteristics crucial.

- Income levels and grid electricity prices dominate regional deployment.

- Low-irradiation western Europe better than high-irradiation Middle East.

\section{A R T I C L E I N F O}

\section{Keywords:}

Rooftop PV

Residential

Technical and economic potential

Integrated assessment model

Cost-supply curves

BIPV

Building integrated photo-voltaic

\begin{abstract}
A B S T R A C T
The use of solar photovoltaic has strongly increased in the last decade. A significant part of this growth comes from home owners installing rooftop photovoltaic. Despite this key role, most long-term model-based scenarios do not consider decentralized supply of rooftop photovoltaic but concentrate on utility-scale photovoltaic instead. In this paper, we implement rooftop photovoltaic in the Integrated Assessment Model IMAGE to study its possible role in energy and climate scenarios. We first calculated the global technical and economic potential to derive regional cost-supply curves for rooftop photovoltaic. Next, we have added a new decision in the IMAGE model allowing household investment in rooftop photovoltaic based on the comparison of the whole-sale electricity price with the price of rooftop photovoltaic. The global suitable roof surface area was assessed at 36 billion $\mathrm{m}^{2}$, or $4.7 \mathrm{~m}^{2}$ capita $^{-1}$, leading to a potential for rooftop photovoltaic of $8.3 \mathrm{PWh}^{-1}$, roughly 1.5 times the 2015 global residential electricity demand. In the baseline scenario, adding rooftop photovoltaic could lead to a $80-280 \%$ increased share of photovoltaic electricity production in 2050 (i.e. from $6 \%$ to $17 \%$ in total power production). This increase depends on regional characteristics that are essential to the deployment of rooftop photovoltaic: differences in social-economic and policy factors (capital costs, household income, and electricity prices) are considerably more important than physical factors, such as solar irradiance.
\end{abstract}

\section{Introduction}

The use of solar photovoltaic (PV) has strongly increased in the last decade. The capacity increased from $6.6 \mathrm{GW}$ to over $500 \mathrm{GW}$ in the 2006-2018 period [1]. Interestingly, the main driver for this development were investments done by home owners in rooftop PV, not investments in utility-scale PV [2,3]. In fact, rooftop PV accounts for the majority of installed capacity today [2]. One reason for this is that home owners perceive the costs of PV differently than utilities. Utilities compare the costs of PV with the whole-sale electricity market with competitive price levels of around 0.03-0.05 $\$ \mathrm{kWh}^{-1}$, currently supplied by coal and gas-fired power plants. Home owners, however, compare the costs of rooftop PV with electricity retail prices. These prices are, in general, considerably higher than electricity market prices because of taxes, and transmission and distribution (T\&D) costs. Home owners can also benefit from subsidies and net-metering. The latter is a

\footnotetext{
* Corresponding author.

E-mail address: david.gernaat@pbl.nl (D.E.H.J. Gernaat).
} 
Table 1

Regional capital costs in $2015\left(\$ \mathrm{~kW}^{-1}\right)$ that were used in this study. Regular font is directly based on IEA [20], italic font indicates the allocation of IEA data to another IMAGE region. Prices were further checked to more recent cost numbers [20], see Appendix, Table A4 for regional capital cost generated by the IMAGE model.

\begin{tabular}{|c|c|c|c|c|}
\hline $\begin{array}{l}\text { IEA } \\
\text { region }\end{array}$ & IMAGE region & $\begin{array}{l}\text { Utility- } \\
\text { scale PV }\end{array}$ & $\begin{array}{l}\text { Additional cost for } \\
\text { rooftop PV }\end{array}$ & $\begin{array}{l}\text { Rooftop PV } \\
\text { O\&M }\end{array}$ \\
\hline Europe & Western Europe & 1320 & 280 & 16 \\
\hline Europe & Central Europe & 1320 & 280 & 16 \\
\hline $\begin{array}{l}\text { United } \\
\text { States }\end{array}$ & US & 2220 & 1260 & 34 \\
\hline $\begin{array}{l}\text { United } \\
\text { States }\end{array}$ & Canada & 2220 & 1260 & 34 \\
\hline $\begin{array}{l}\text { United } \\
\text { States }\end{array}$ & Oceania & 2220 & 1260 & 34 \\
\hline Japan & Japan & 2020 & 860 & 28 \\
\hline Japan & Korea & 2020 & 860 & 28 \\
\hline Russia & Russia & 2580 & 900 & 34 \\
\hline Russia & Turkey & 2580 & 900 & 34 \\
\hline Russia & Ukraine & 2580 & 900 & 34 \\
\hline Russia & Central Asia & 2580 & 900 & 34 \\
\hline China & China + & 1360 & 120 & 14 \\
\hline China & $\begin{array}{l}\text { Southeastern } \\
\text { Asia }\end{array}$ & 1360 & 120 & 14 \\
\hline China & Indonesia & 1360 & 120 & 14 \\
\hline China & Rest of south Asia & 1360 & 120 & 14 \\
\hline India & India + & 1340 & 120 & 14 \\
\hline $\begin{array}{c}\text { Middle } \\
\text { East }\end{array}$ & Middle East & 2360 & 640 & 30 \\
\hline Africa & Northern Africa & 2400 & 440 & 28 \\
\hline Africa & Western Africa & 2400 & 440 & 28 \\
\hline Africa & Eastern Africa & 2400 & 440 & 28 \\
\hline Africa & Southern Africa & 2400 & 440 & 28 \\
\hline Africa & $\begin{array}{l}\text { Rest of southern } \\
\text { Africa }\end{array}$ & 2400 & 440 & 28 \\
\hline Brazil & Brazil & 1980 & 700 & 30 \\
\hline Brazil & Mexico & 1980 & 700 & 30 \\
\hline Brazil & $\begin{array}{l}\text { Rest of Central } \\
\text { America }\end{array}$ & 1980 & 700 & 30 \\
\hline Brazil & $\begin{array}{l}\text { Rest of South } \\
\text { America }\end{array}$ & 1980 & 700 & 30 \\
\hline
\end{tabular}

policy instrument allowing home-owners to sell excess electricity to the grid at retail price. Net-metering is, for instance, allowed in several states in the US and some European countries to incentivize rooftop PV investments [4]. The competitive position of PV thus not only depends on differences in solar irradiation, but also on these regional factors such as retail electricity prices, taxes, policies, and capital cost. This is, for instance, clearly shown by Lang [5] indicating that PV can be more attractive in a low-irradiation country like Germany than a highirradiation country like Qatar. The same was demonstrated comparing Germany with California $[6,7]$.

Scenarios developed by Integrated Assessment Models (IAMs) are used to inform policy makers on choices regarding energy and climate
PV technology in the IMAGE IAM. The possibility for households to decide for rooftop PV was modelled trough a new investment decision that compares the whole-sale electricity price with the price of rooftop PV. This decision was implemented with region specific characteristics, such as income levels, retail electricity prices, taxes, and investment levels. For the latter, the Shared Socio-economic Pathways (SSPs) scenarios, as implemented in IMAGE, were used to explore long-term development [12].

\section{Methods}

In order to estimate the economic potential for rooftop PV and implement this in IMAGE, several steps were taken that are explained in the sections below. First, we assessed the technical potential of rooftop $\mathrm{PV}$ based on residential roof area (see Section 2.1.1). Next, we combined the technical potential with economic information to derive cost-supply curves (see Section 2.1.2). Subsequently, we estimated the role of solar rooftop PV in future energy systems using the IMAGE model (see Section 2.2) and the SSP scenarios (see Section 2.3). For a schematic representation of the methodology see the flow chart in Appendix, Fig. A1.

\subsection{Cost-supply curves of rooftop PV}

\subsubsection{Technical potential of rooftop $P V$}

We use Eq. (1) to calculate the potential annual electricity from rooftop surfaces $\left(\mathrm{E}_{\mathrm{rt}}\right)\left(\mathrm{kWh} \mathrm{y}^{-1}\right)$ :

$E_{r t}=G \cdot \eta \cdot P R \cdot S R A$

where $\mathrm{G}$ is the solar irradiation based on the NASA SSE6 Global Horizontal Radiation dataset available in $0.5^{\circ} \times 0.5^{\circ}\left(\mathrm{kWh} \mathrm{m}^{-2} \mathrm{y}^{-1}\right), \eta$ is the panel efficiency, $P R$ is the performance ratio expressing the difference between performance under standard test conditions the actual output of the system due to losses from sub-optimal angles and cable or inverter losses, and SRA the suitable roof area (see Eq. (2)). For the panel efficiency, $17 \%$ is chosen to represent modern crystalline Silicon panels $[13,14]$. A PR of $85 \%$ is chosen to reflect increasing capacity factors of recent years $[13,14]$. Data for roof area (SRA) is harder to obtain, as a global dataset does not exist. Instead, we have used estimates for floor space, in combination with census data on the number of floors per household (Eq. (2)). Daioglou [15] identified a relationship between floor space and household expenditures. According to this, floor space is linearly related to household expenditures, while population density logarithmically decreases floor space. The relationship distinguishes between urban and rural households, allowing for larger floor spaces in rural households despite lower household expenditures. This function (see Eq. (2), second part) was calibrated on available statistical data from the WorldBank [16] $\left(\mathrm{R}^{2}=0.67\right)$. We used the following equation to convert floor space into roof area per household h, per region $r$ (Appendix, Fig. A2 for IMAGE regions), per division (urban/ rural) i:

$\left.S R A_{h, r, i}=F_{h, r, i} \cdot \beta_{r} \cdot S=\left(x_{1} \cdot \ln \left(P D_{r}\right)+x_{2}\right) \cdot\left(1+\frac{\alpha \cdot H E_{r}}{35000}\right) \cdot e^{-\varphi_{2} e^{-\left(\frac{\varphi_{3}}{1000}\right)}}\right) \cdot\left(x_{3} \cdot U_{r}+x_{4}\right) \cdot \beta_{r} \cdot S$

issues. Given the importance of rooftop PV in the past, one might expect that IAM scenarios would include an adequate description of its dynamics. Most IAM scenarios, however, do not consider rooftop PV but concentrate on utility-scale PV instead [8-11]. In this paper, we aim to develop an estimate of the economic potential of rooftop PV, and implement this technology in an IAM to study its possible role in longterm energy and climate scenarios. For this, we derived regional costsupply curves for rooftop PV and used these curves to create a rooftop where $\mathrm{SRA}_{\mathrm{h}, \mathrm{r}, \mathrm{i}}$ is the suitable roof area $\left(\mathrm{m}^{2}\right), \mathrm{F}_{\mathrm{h}, \mathrm{r}, \mathrm{i}}$ is the floor space $\left(\mathrm{m}^{2}\right)$ as calculated by Daioglou [15], $\beta_{\mathrm{r}}$ is the coefficient that converts floor space into roof area, and $\mathrm{S}$ is the coefficient that converts roof area into suitable architecturally available area for PV (0.32, see below for a further description). Floor space itself $\left(\mathrm{F}_{\mathrm{h}, \mathrm{r}, \mathrm{i}}\right)$ was calculated as described by the second part of Eq. (2) [17], where $\mathrm{x}_{1}$ is $-2.964, \mathrm{PD}_{\mathrm{r}}$ is the population density (capita km ${ }^{-2}$ ), $\mathrm{x}_{2}$ is $60.577, \alpha$ is $0.125, \mathrm{HE}_{\mathrm{r}}$ is household 
expenditure ( $\$$ household ${ }^{-1}$ ), $\phi_{2}$ is $1.341, \phi_{3}$ is $0.125, \mathrm{x}_{3}$ is 0.289 and $\mathrm{U}_{\mathrm{r}}$ is the population division factor (urban/rural) and $x_{4}$ is 0.717 .

The $\beta$ coefficient is based on the number of floors per household. A household with three floors (ground floor, 1st floor, and 2nd floor), for example, has a $\beta$ coefficient of 0.33 because the roof area equals a third of the floor space. The number of floors were taken from census data available for twenty countries that cover eleven IMAGE regions (see Appendix, Table A1). For the remaining regions, we estimated a coefficient based on the resemblance with other regions. This way we matched, for example, Canada to the US (see Appendix, Tables A2 and A3). In other cases, we used the global average. The $\beta$ coefficients show clear regional differences. The US, for example, have a $\beta$ coefficient of 0.46 , reflecting a low-rise building style. In contrast, the $\beta$ of Japan ( 0.3$)$, reflects a high-rise building style. The available roof area thus differs depending on cultural characteristics. We assume these characteristics to stay the same in our scenario analyses (an assumption further discussed in Section 4).

The total rooftop area was multiplied by a suitability coefficient ( $\mathrm{S}$ in Eq. (2)) to account for roof types (flat or tilted), shading, orientation, and architectural obtrusions. Based on a study that used high-resolution satellite data to assess available roof area in the US [18] this number was chosen to be 0.32 . Due to lack of data we could not implement regional differentiation (an assumption further discussed in Section 4).

The regional roof areas were scaled down to a $0.5^{\circ} \times 0.5^{\circ}$ global map based on geographic population data to distinguish between rural and urban population [19]. This roof area map was combined with the solar irradiation data to obtain the annual technical potential of rooftop PV per grid cell.

\subsubsection{Costs of rooftop $P V$}

The levelized costs for rooftop PV (LCOE) $\left(\$ \mathrm{kWh}^{-1}\right)$ were calculated at the $0.5^{\circ} \times 0.5^{\circ}$ grid using the following equation per grid cell $i$ and per region $\mathrm{r}$ :

$L C O E_{i}=\frac{a n n \cdot\left(I_{r}+\varepsilon_{r}\right) \cdot y_{r}+a n n \cdot\left(I_{-} R T_{r}+\varepsilon_{-} R T_{r}\right) \cdot y_{-} R T_{r}}{E_{i}}$

where ann is the annuity factor (20 year lifetime, $10 \%$ discount rate), $\mathrm{I}_{\mathrm{r}}$ are the regional investment costs for utility scale $\mathrm{PV}\left(\$ \mathrm{~kW}^{-1}\right), \varepsilon_{\mathrm{r}}$ are the O\&M costs for utility scale PV $\left(\$ \mathrm{~kW}^{-1}\right), \gamma_{\mathrm{r}}$ is the technology improvement of utility-scale PV (see Eq. (4)), I_RT $\mathrm{r}_{\mathrm{r}}$ and $\varepsilon_{-} \mathrm{RT}_{\mathrm{r}}$ are the additional costs for rooftop PV $\left(\$ \mathrm{~kW}^{-1}\right), \gamma_{\mathrm{r}}$ is the technology development of rooftop PV (see Eq. (4)), and $E_{\mathrm{i}}$ is the electricity produced in the grid cell (see Eq. (1)). For utility-scale PV costs $\left(I_{r}\right.$ and $\left.\varepsilon_{r}\right)$, we used data on capital costs from the IEA [20] resulting in regional costs ranging from 1320 \$ $\mathrm{kW}^{-1}$ in Europe to $2580 \$ \mathrm{~kW}^{-1}$ in Russia (see Table 1). Additional costs to install rooftop PV ( $\mathrm{I}_{-} \mathrm{RT}_{\mathrm{r}}$ and $\varepsilon_{-} \mathrm{RT}_{\mathrm{r}}$ ) on residential roofs were also based on IEA [20] (Table 1) and range from $120 \$ \mathrm{~kW}^{-1}$ in China to 1260 $\$ \mathrm{~kW}^{-1}$ in the US; as were operation and maintenance (O\&M) costs. See Appendix, Table A4, for regional technical details.

The large variations in regional capital costs have various reasons. Firstly, some regions, such as the US, have trade barriers protecting domestic industries. Secondly, some regions are more experienced than others in the installation of PV systems. Europe, for example, has had an active PV industry in the last decade but this is less for other regions, such as the US. Exchanging knowledge with trading PV panels is easy, but transferring experience on installation skills is difficult. Thirdly, some regions, such as China, are producers of PV panels while others, such as Africa, are importers. Finally, developing regions have lower wages compared to developed regions resulting in lower production and installation cost. As these differences in costs clearly exist, it is important to include them in the model.
In the future we expect these regional capital costs to converge due to learning effects, information sharing, and trade. In our default scenarios, we assume convergence of costs, for both utility-scale and rooftop PV, to European levels within approximately ten years (2025). We chose European cost levels (280 $\$ \mathrm{~kW}^{-1}$ additional cost for rooftop PV) over Chinese and Indian levels (120 $\$ \mathrm{~kW}^{-1}$ ) due to the expected rise of labour costs in China and India. Lastly, in our long-term scenario, we assume a floor cost of $150 \$ \mathrm{~kW}^{-1}$ to prevent utility-scale PV costs going to near-zero.

The costs for both utility-scale PV and rooftop PV declined 40-75\% between 2010 and 2015 [1,2,20,21]. For technology development, we applied a so-called learning curve that assumes that costs decrease endogenously as a function of the cumulative energy capacity as indicated in Eq. (4):

$\gamma=\alpha Q^{-\pi}$

where $\pi$ is the learning rate (20\%), Q the cumulative capacity, and $\alpha$ is the cost of the first unit produced. The learning rate, often indicated as the progress ratio, indicates how fast costs decrease with a doubling of cumulative capacity (progress ratio $=2^{-\pi}$ ).

The historical trend fits a historical learning rate of $20 \%$ (see Appendix, Table A4). This rate we also used for future scenarios for both direct costs for PV modules and additional costs for the rooftop PV system. The costs for the PV system are increasingly determined by nonmodule cost, such as support, cables, or inverters. There is, however, little evidence that the non-module part has a different learning rate. In fact, there is more evidence for similar learning rates [22-24].

Finally, the annual information of technical potential and costs are calculated at $0.5^{\circ} \times 0.5^{\circ}$ grid. The data is subsequently converted in cost-supply curves per IMAGE regions by sorting, from low to high, the grid cells on costs, while simultaneously adding the same cells from the technical potential map (see Appendix, Fig. A2 for the IMAGE regions).

\subsection{Implementation of rooftop PV in IMAGE}

\subsubsection{IMAGE integrated assessment model}

We use the cost-supply curves in IMAGE to study the long-term role of rooftop PV in future energy system. IMAGE has been developed to study global environmental change by describing the key interactions between humans and the environment. Within IMAGE, the energysystem model TIMER describes the energy system for 26 world regions in terms of energy demand and energy supply. Energy demand starts from the energy services that generate energy use, such as transportation, heating, or lighting. The demand for services is based on economic activities. These are modelled in detail in some cases (e.g. residential sector) but in other cases they are derived directly from changes in GDP. The demand for energy can be fulfilled by various energy carriers. Choosing between these carriers depends on relative prices and preferences. By correcting for end-use efficiencies, the demand for secondary energy (e.g. electricity, gasoline, or hydrogen) is derived, which is subsequently supplied by primary energy carriers that undergo several conversions steps; electricity demand, for example, is based on the underlying demand for fossil fuels, nuclear power, and renewables.

The long-term costs of primary energy carriers are based on technology development and resource depletion. Technological development is implemented in the form of learning curves, decreasing the cost over time as more is used. Resource costs, however, increase as they get depleted, which is modelled with the cost-supply curve information (such as derived for rooftop PV in 2.12). Below, we describe methods used to estimate rooftop PV cost-supply curves and how these costsupply curves are implemented in IMAGE [25]. The use of rooftop PV 


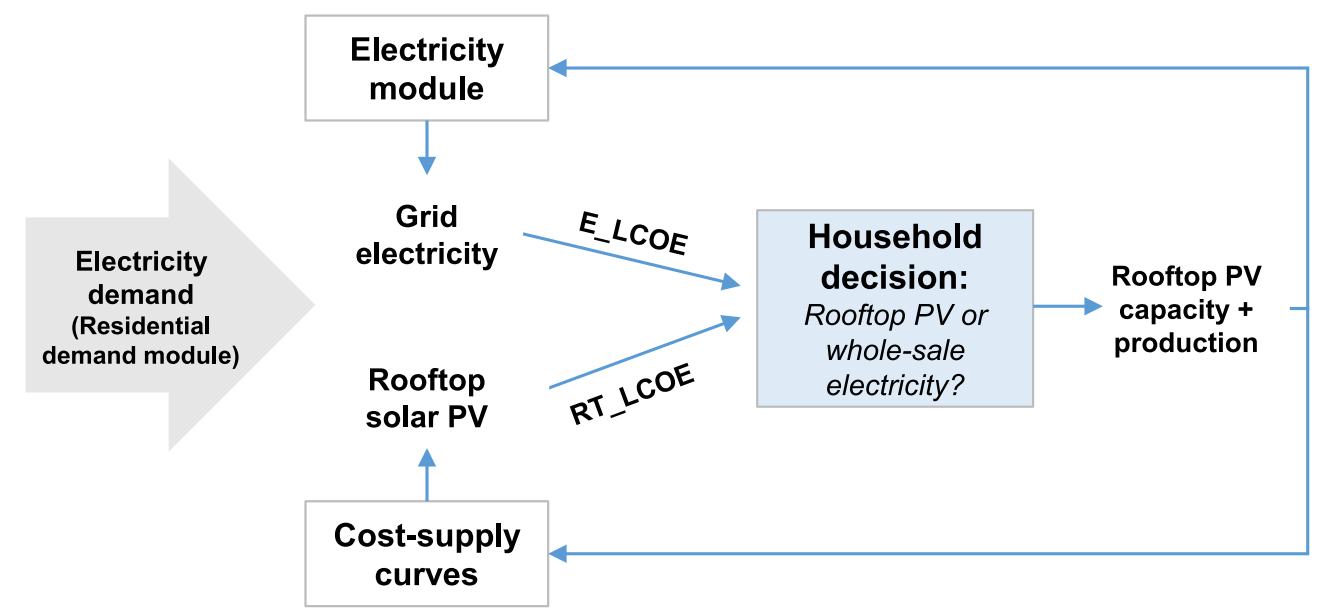

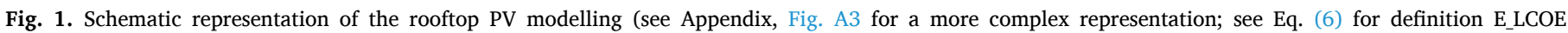
and RT_LCOE).

is determined in the residential energy demand model, where it competes with grid-based electricity.

\subsubsection{Grid-based electricity}

The electricity module simulates the generation of 28 different combinations of renewable, nuclear, fossil-fuel, and bio-energy technologies. It is described in detail in the Appendix, Text A1. The 28 technologies compete for market-shares in the supply of electricity based on relative costs and additional system factors for reliability requirements. The electricity price is calculated based on the costs of the resulting system [26].

\subsubsection{The use of rooftop $P V$}

The residential energy-demand module describes the energy choices made by households for heating, cooling, cooking, lighting, and appliances (see Appendix, Fig. A3 for a schematic representation from Daioglou [15]). The model distinguishes between urban and rural households, each represented by five income groups. Several physical and economic drivers, such as population density, income levels, temperature, and floor space, are involved to calculate the demand for these end-use energy services.

The fuel choice is based on the perceived costs of various alternatives. Here, income levels play a key role. Low-income groups have lower liquidity and difficult access to loans; high-income groups, however, have higher liquidity and easier access to loans. High-income groups are therefore more likely to make long-term investments. These different behaviours are described with consumer discount rates (CDRs): a high discount rate for low-income groups and a low one for high-income groups. Empirical evidence indicates that CDRs can be as high as $80 \%$ for low-income groups but as low as $10 \%$ for high-income groups $[27,28]$. In the residential energy-demand module, the CDRs depend on household expenditures and are described by Eq. (5) per region $r$, per division (urban/ rural) $\mathrm{i}$, per income quintile $\mathrm{j}$ :

$C D R_{r, i, j}=x_{1}+e^{x_{2}-x_{3} \cdot H E_{r, i, j}}$

where $\mathrm{x}_{1}$ is $10, \mathrm{x}_{2}$ is $6.902, \mathrm{x}_{3}$ is 0.008 and $\mathrm{HE}_{\mathrm{r}, \mathrm{I}, \mathrm{j}}$ is the household expenditure ( $\$$ household $^{-1}$ ) based on data from WorldBank [16].

In IMAGE, we apply this equation to the five different income groups per region for urban and rural population. The costs of fuel alternatives for each income group are subsequently calculated using the discount rates. Given the difference in investment costs for various fuel alternatives, the emergent behaviour leads to trends that represent the energy ladder (fuel switching behaviour from fuels with low-investment costs, such as wood, to modern fuels with high-investment costs, such as electricity) [29]. The relative costs are also influenced by additional price factors such as taxes, subsidies, and distribution costs. Data on these components are based on Jewell [30].

A new decision was implemented in the model that determined whether a household buys whole-sale electricity from the grid, or invests

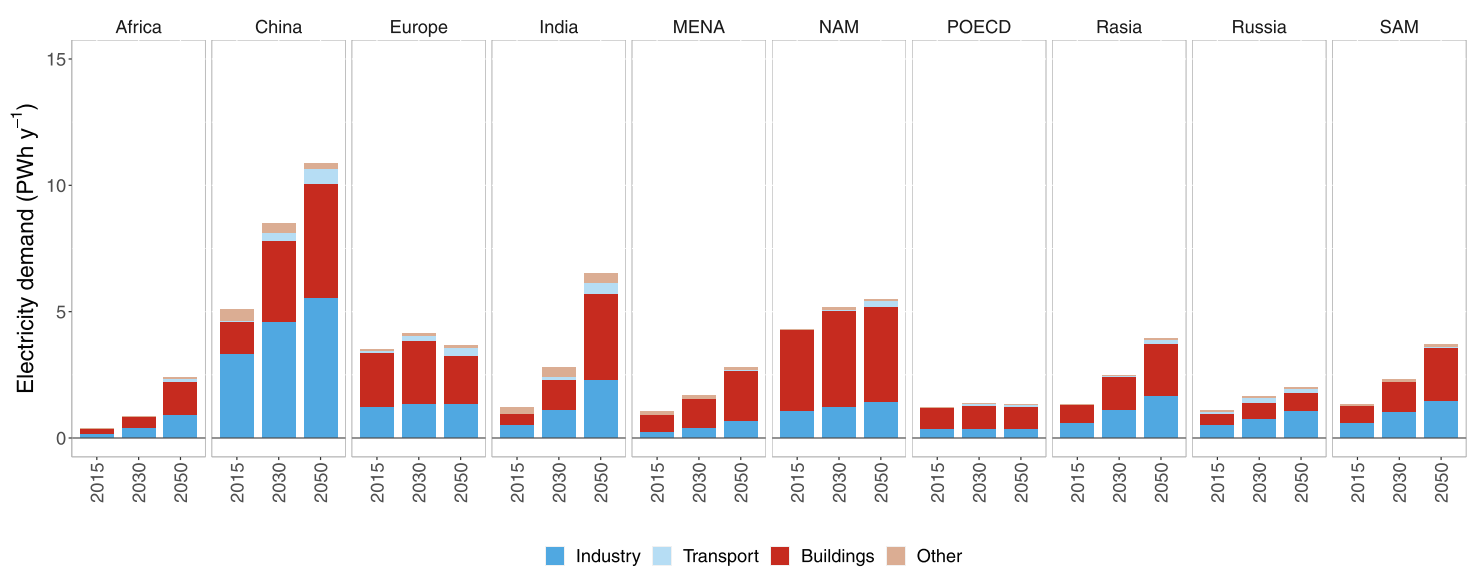

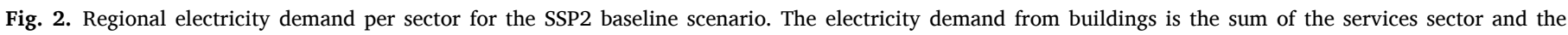

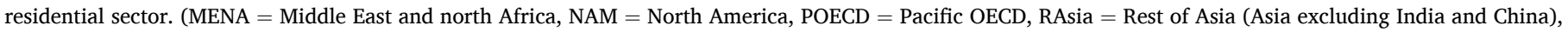
$\mathrm{SAM}=$ South America). 
Table 2

Scenarios used in this study. See Appendix, Text A2 and Figs. A4, A5 for a detailed explanation of the SSP scenarios.

\begin{tabular}{|c|c|c|}
\hline Scenario name & Abbreviation & Explanation \\
\hline $\begin{array}{l}\text { Baseline without } \\
\text { rooftop PV }\end{array}$ & SSP2 & $\begin{array}{l}\text { SSP2 baselines, no climate policy, } \\
\text { without rooftop PV }\end{array}$ \\
\hline $\begin{array}{l}\text { Baseline with } \\
\text { rooftop PV }\end{array}$ & SSP2_RT & $\begin{array}{l}\text { SSP2 baseline, no climate policy, with } \\
\text { rooftop PV but without net-metering } \\
\text { policy }\end{array}$ \\
\hline Rooftop PV Policy & SSP2_RTPol & $\begin{array}{l}\text { SSP2 baseline, no climate policy, with } \\
\text { rooftop PV and net-metering policy }\end{array}$ \\
\hline $\begin{array}{l}\text { Climate policy } \\
\text { without rooftop } \\
\text { PV }\end{array}$ & SSP2_ClimPol & $\begin{array}{l}\text { SSP } 2 \text { with radiative forcing target of } \\
2.6 \mathrm{~W} \mathrm{~m}^{-2} \text { in } 2100 \text {, without rooftop PV } \\
\text { and net-metering policy }\end{array}$ \\
\hline $\begin{array}{l}\text { Climate policy } \\
\text { with rooftop PV }\end{array}$ & SSP2_RTPol_ClimPol & $\begin{array}{l}\text { SSP } 2 \text { with radiative forcing target of } \\
2.6 \mathrm{~W} \mathrm{~m}^{-2} \text { in } 2100 \text {, with rooftop PV } \\
\text { and net-metering policy }\end{array}$ \\
\hline
\end{tabular}

in rooftop PV (see Fig. 1).

The new investment decision enables households to either buy whole-sale electricity from the grid or invest in rooftop PV. This decision is modelled with a multi-nomial logit (see Eq. (6)) and compares the prices of whole-sale electricity and a rooftop PV system. Eq. (6) assigns the largest share to the lowest cost option, but also assigns some share to a higher cost option. The market share (MS) (\%) for option a compared to option $b$, per household $i$, per income quintile $j$, and per region $r$ (van Vuuren, 2007) equals:

$M S_{i, j, r}^{a}=\frac{\exp -\lambda\left(E_{-} L C O E_{i, j, r}\right)_{a}}{\left.\sum_{b} \exp -\lambda\left(R T_{-} L C O E_{i, j, r}\right)_{b}\right)}$

where E_LCOE is the levelized cost of electricity (LCOE) from the electricity module $\left(\$ \mathrm{kWh}^{-1}\right)$, RT_LCOE is the LCOE of rooftop PV ( $\$$ $\mathrm{kWh}^{-1}$ ), and $\lambda$ is the so-called logit parameter that reflects the behavioural sensitivity to prices. This parameter was calibrated to historically observed sensitivity to prices. The rooftop electricity costs were calculated following Eq. (3), with an exception that the annuity factor (ann) is now calculated for the individual income groups with the CDR from Eq. (5). An important assumption, as indicated in Eq. (3), is that we assume that rooftop PV is comprised of similar technological components as utility-scale PV. Yet, we also assume that there are additional costs incurred with rooftop installation. This means that the technology development based on the learning curve (see Eq. (4)) is influenced by the capacity of both utility-scale PV and rooftop PV.

The total rooftop PV capacity (sum of all urban/rural/income
Table 3

Comparing calculated roof areas and technical potentials to literature.

\begin{tabular}{clll}
\hline Region & Source & $\begin{array}{l}\text { Suitable roof area } \\
\left(\mathrm{km}^{2}\right)\end{array}$ & $\begin{array}{l}\text { Technical potential } \\
\left(\mathrm{TWh} \mathrm{y}^{-1}\right)\end{array}$ \\
\hline Global & $\begin{array}{l}\text { Hoogwijk et al. } \\
\text { (2004) }\end{array}$ & 150,000 & 6000 \\
& This study & 36,237 & 8310 \\
Global & Deng [35] & 40,000 & 8611 \\
& This study & 36,237 & 8310 \\
Global & OECD/IEA [39] & 25,000 & 5800 \\
urban & This study & 18,550 & 4161 \\
US & Gagnon et al. & 4950 & $926^{1}$ \\
& (2016) & & \\
EU & This study & 2637 & 591 \\
& Defaix et al. & 3678 & $840^{2}$ \\
(2014) & & 705 \\
Spain & This study & 4015 & 42 \\
\multirow{2}{*}{ Switzerland } & Izquierdo [37] & 571 & 71 \\
& This study & $950^{3}$ & 18 \\
& Assouline [38] & 328 & 7 \\
\hline
\end{tabular}

1 Only the small building class $\left(<5000 \mathrm{ft}^{2}\right)$.

2 The total potential Defaix et al. (2012) is $840 \mathrm{TWh} \mathrm{y}^{-1}$, this includes commercial buildings and facades. Subtracting the commercial area $\left(1301 \mathrm{~km}^{2}, 24 \%\right.$ of total surface) reduces the potential to $620 \mathrm{TWh}^{-1}$. There are also mismatches on countries compared to the numbers in calculated in this article. The numbers of this study are calculated with EU defined as IMAGE regions western Europe and eastern Europe.

${ }^{3}$ Does not include the suitability coefficient (S in Eq. (2); 0.32) to improve comparability with the reference.

groups) is added to the general power pool of the electricity module. This ensures that rooftop PV contributes to the technological learning equations, but also ensures that the electricity system includes rooftop PV in operational issues that relate to intermittency and grid stability (see Appendix, Text A1, for more detail on the electricity module). Finally, a self-consumption rate of $30 \%$ is assumed, to model that households, on average, consume some of the electricity directly inside the household, without supplying it to the grid (Lang et al., 2015). This factor is kept constant over time.

\subsection{Scenarios}

In order to assess the role of rooftop PV in future energy systems, we use the IMAGE implementation of the SSP2 scenario [12,31]. The SSP2 scenario describes a world in which social, economic, and technological
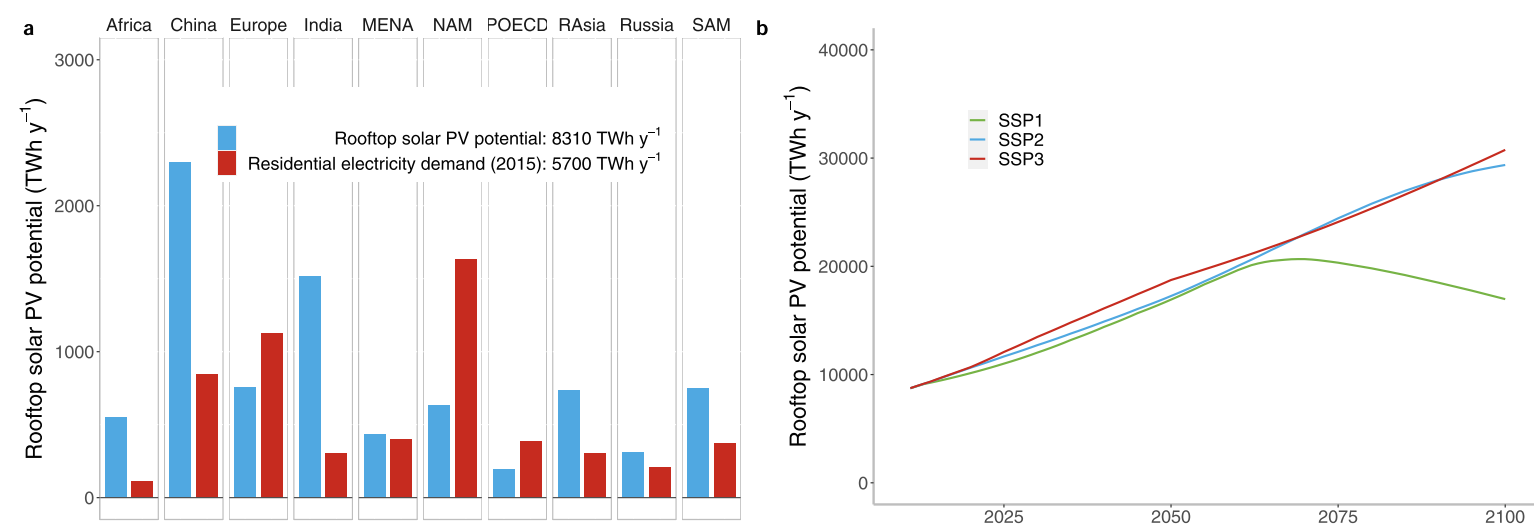

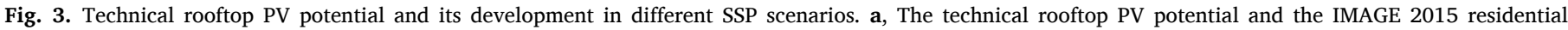

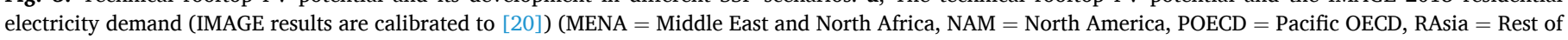

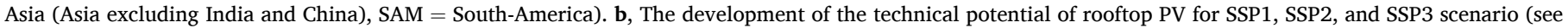
Appendix, Text A2 and Figs. A4, A5 for more details on the SSP scenarios). 


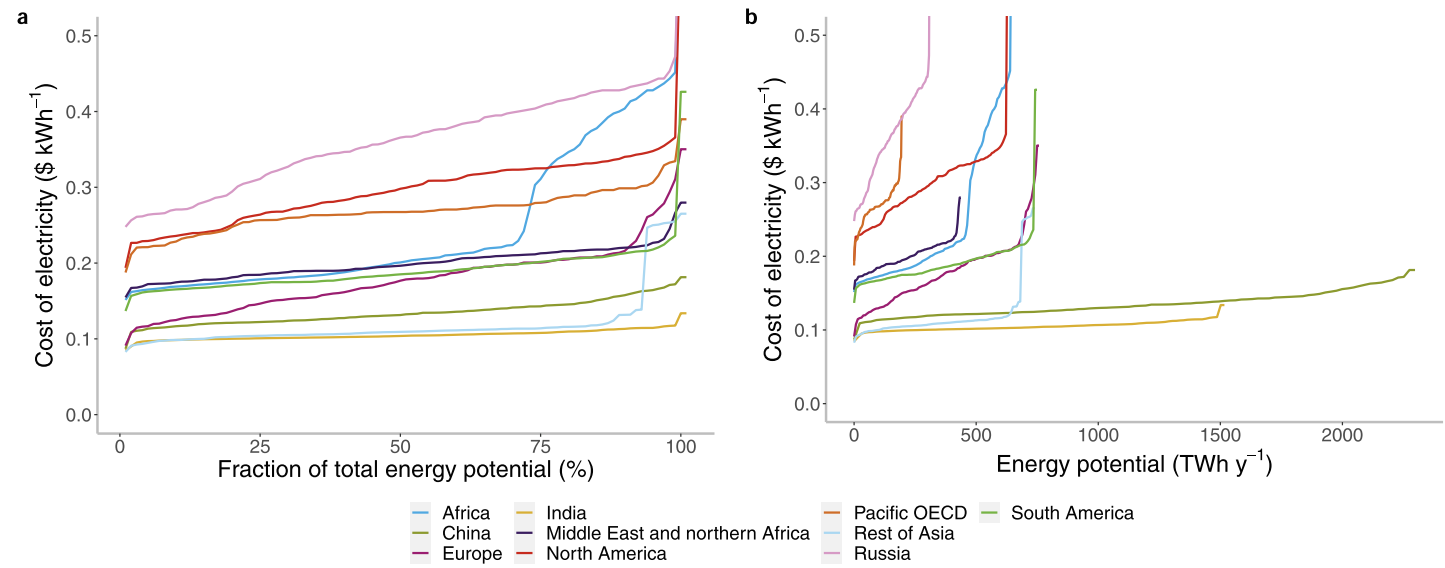

Fig. 4. Regional cost-supply curves for rooftop PV. a, Relative to technical potential and b, Absolute cost-supply curves.

trends follow a median trajectory. The economic development in this scenario is modest and population growth follows a median scenario more-or-less levelling off in the second half of the century (for more information see Appendix, Text A2 and Figs. A4, A5). The regional electricity demand per sector for the IMAGE-SSP2 baseline scenario is shown in Fig. 2. In this scenario global electricity demand doubles by 2050, but regions like India, however, are expected to grow fivefold. Most of this growth comes from the residential sector, the services sector, and industry sector, but some growth is also expected from the transport sector. Compared to the industry sector, the building sector grows faster because of a higher electrification rate, a growth in the services sector, and a growth of household floor space.

We defined five scenarios to explore the impact of the rooftop PV in future energy systems (Table 2). These scenarios combine climate policy with specific policy factors for rooftop PV. At first, a baseline scenario with (SSP2_RT) and without (SSP2) rooftop PV. Then, an additional baseline scenario that includes a net-metering policy (SSP2_RTPol). Subsequently, a climate-policy scenario with (SSP2_RTPol_ClimPol) and without (SSP2_ClimPol) rooftop PV-including net-metering for the scenario with rooftop PV. To emphasize levels of uncertainty, we show the results for other SSPs at several occasions (see Appendix, Text A2 and Figs. A4, A5 for more details on the SSP scenarios).

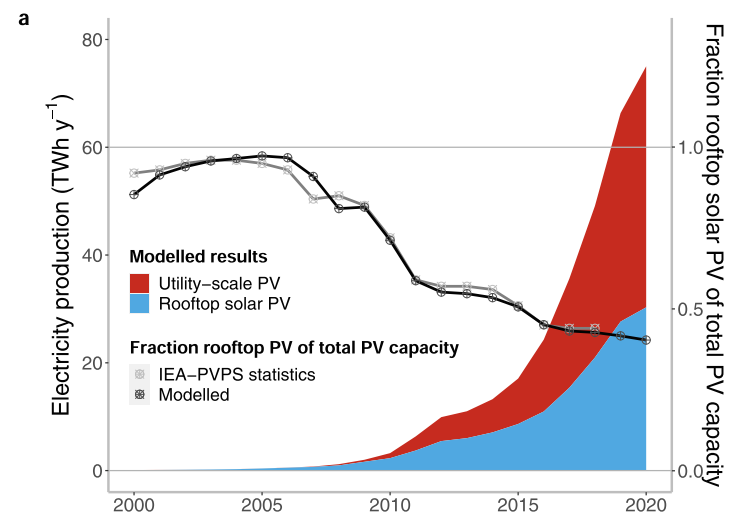

\section{Results}

\subsection{Technical and economic potential of rooftop $P V$}

We estimated a global roof area of 113 billion $\mathrm{m}^{2}$, with 36 billion $\mathrm{m}^{2}$ being potentially suitable for rooftop PV which equals $4.7 \mathrm{~m}^{2}$ capita ${ }^{-1}$. Estimates of available roof area in the Netherlands show $7.3 \mathrm{~m}^{2}$ capita $^{-1}$ (using the suitability factor in this study), which is similar to our western European estimate $\left(7.4 \mathrm{~m}^{2}\right.$ capita $\left.^{-1}\right)$ [32]. Combined with irradiance data and conversion efficiencies this leads to a global annual potential of rooftop PV 8.3 $\mathrm{PWh}^{-1}$. This is roughly 1.5 times the global residential electricity demand in 2015 (Fig. 3a). The global average production per square meter is $230 \mathrm{kWh} \mathrm{m}^{-2} \mathrm{y}^{-1}$. This is roughly compatible with empirical findings in The Netherlands, showing an average production of the current installed capacity of $140 \mathrm{kWh} \mathrm{m}^{-2} \mathrm{y}^{-1}$ (if we look at Dutch grid cells, we find 141-167 $\mathrm{kWh} \mathrm{m}^{-2} \mathrm{y}^{-1}$ ) [33]. The potential for rooftop $\mathrm{PV}$ is particularly high in China, India, western Europe, and the US, which can be explained by the large available roof area. In China and India, the roof area is driven by a large population, but in western Europe and the US roof area is driven by larger household floor spaces. Over time, the potential grows as a function of an increase in floor space, which is driven by population, GDP, and household size (Fig. 3b). The global rooftop PV potential doubles by 2050 in all SSP scenarios (see Appendix, Text A2 and Figs. A4, A5 for more details on the SSP scenarios, including SSP1 and SSP3).

In Table 3 we present our results on roof area and technical potential estimates in comparison with data presented earlier. Starting with the b

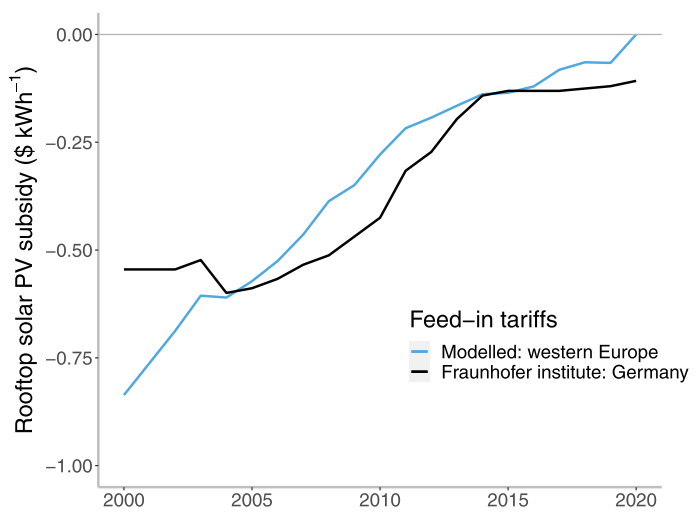

Fig. 5. Historical development of utility-scale PV and rooftop PV, and its subsidies. a, The modelled historical development of utility-scale PV and rooftop PV in PWh $\mathrm{y}^{-1}$, compared to statistical data from IEA-PVPS reports between 2000 and 2019 [3]. b. The calculated subsidies for the western Europe and the German subsidy [40]. 
a

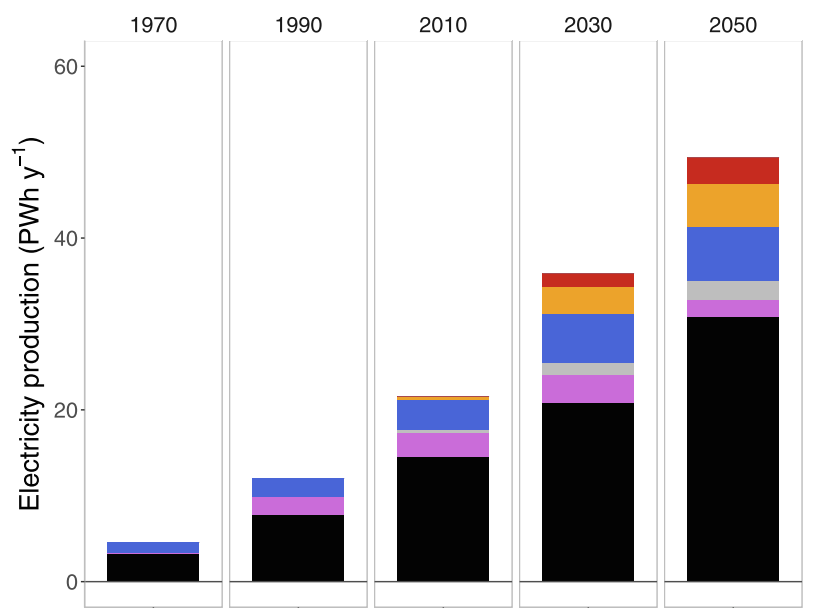

b

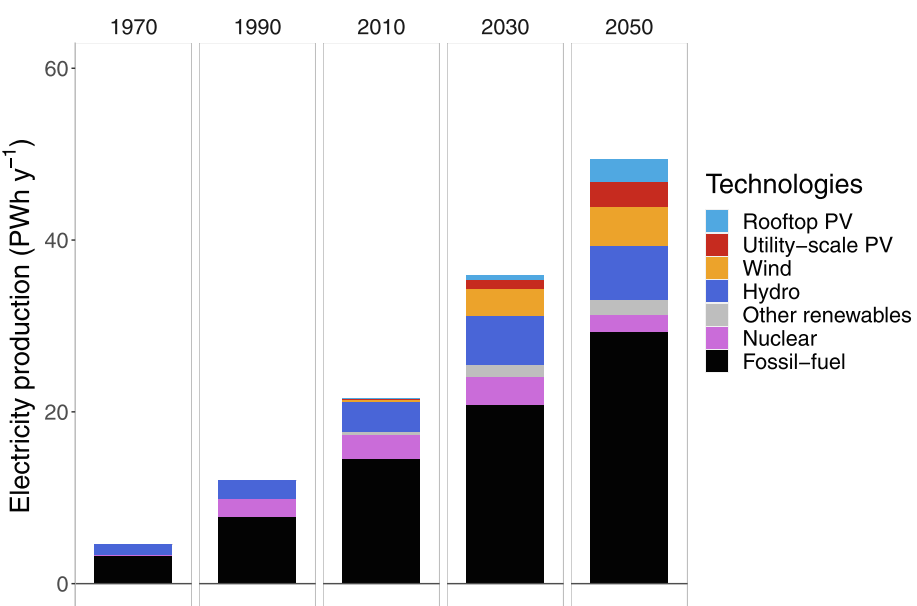

Fig. 6. The electricity production development from 1970 to 2050. a, SSP2 without rooftop PV. b, SSP2 with rooftop PV.
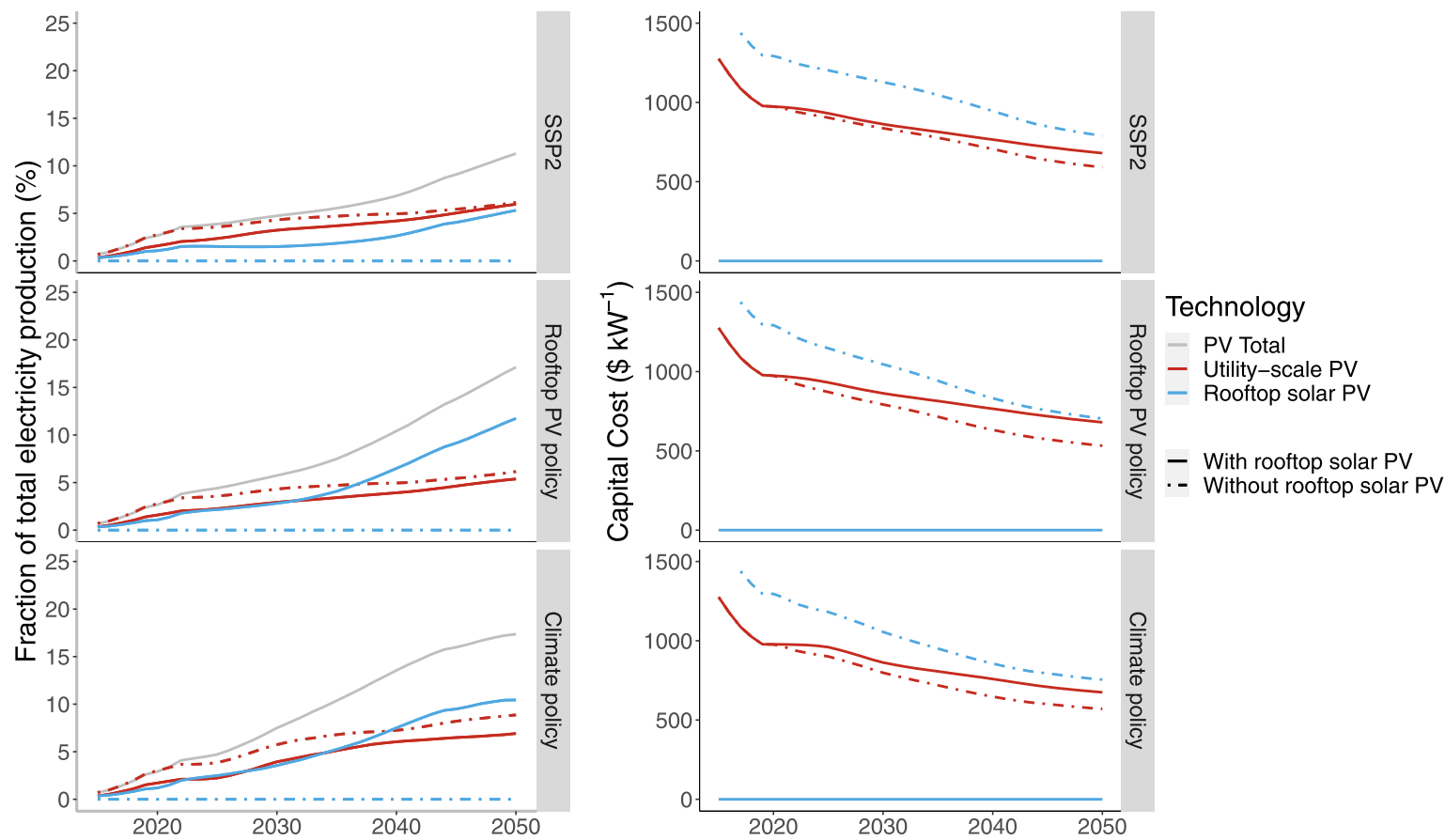

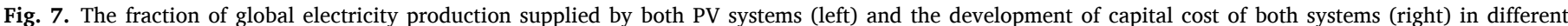

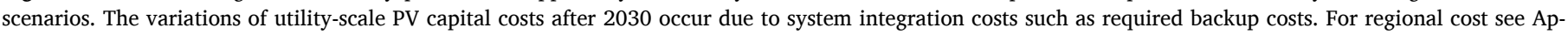
pendix, Table A4.

area, Hoogwijk [34] estimated a global suitable roof surface area of $15,000 \mathrm{~km}^{2}$ based on an aggregated analysis relating GDP per capita directly to roof surface area. Our estimates are about a third of that value $\left(36,237 \mathrm{~km}^{2}\right)$, but is similar to results from Deng [35] who used a methodology similar to ours. Our estimates for the US $\left(2,637 \mathrm{~km}^{2}\right)$ are lower than those of Gagnon [18] (4950 $\left.\mathrm{km}^{2}\right)$, because we do not include service sector buildings. Our EU roof surface estimates $\left(4,015 \mathrm{~km}^{2}\right)$ are in the same range as the ones from Defaix [36] $\left(3,678 \mathrm{~km}^{2}\right)$. The highly detailed regional studies for Switzerland and Spain show some similarity but also differences [37,38]. Comparing the potential, Deng [35] estimates are close to this study, as are the estimates for the US and the EU.

Using Eq. (3) and the capital costs from Table 1, we calculated the LCOE of rooftop PV per grid cell $\left(\$ \mathrm{kWh}^{-1}\right.$ cell $\left.^{-1}\right)$. Combining this LCOE map with the rooftop PV technical potential map ( $\mathrm{kWh}$ cell ${ }^{-1}$ ), costsupply curves were generated by sorting (from low to high) the cells in the LCOE map while simultaneously adding the same cells from the technical potential map. Fig. 4 shows the regional cost-supply curves for ten major world regions in relative (Fig. 4a) and in absolute form (Fig. 4b). Distinct patterns are seen across regions. First, every region 
starts at a different cost level because each region has different investment costs (Table 1). Second, the shape of the curves differs per region. The region named 'rest of Asia' (that is Asia excluding China and India), for example, shows a distinctly flat shape with a large fraction of its potential at low costs. In contrast, Europe shows a steeper shape with costs increasing as more potential is used. Note that, over time, the regional specific capital costs decline with technological learning and converge in the scenarios.

\subsection{Model calibration for historical period}

After introducing the cost-supply curves to the IMAGE model we calibrated the model to statistical data. This calibration was done by adding subsidy to the price of rooftop PV that is necessary to achieve the amount of capacity as reported by IEA-PVPS [3], from which the fraction of rooftop PV also was extracted. The subsidies are calculated in two steps. The first step forces the model to install the historical amount of PV capacity (utility-scale + rooftop PV). In a second step, the reversed multi-nomial logit function (Eq. (6)) is used to calculate the required subsidy. In Fig. 5a the modelled results are presented and compared to the IEA-PVPS 2000-2019 statistical data [3]. The results in Fig. 5a were generated by using subsidies shown in Fig. 5b, which is compared to the historical feed-in tariffs from Germany.

Although comparable, the calculated subsidy is lower than the subsidy from Germany, also called a feed-in tariff [40]. This has several reasons. First, the calculated subsidy is for the whole of western Europe and includes high-irradiance areas such as Spain. Secondly, the average whole-sale electricity price for western Europe is lower than for Germany. Thirdly, this is a result of the multi-nominal logit function. A logit formulation, by definition, allows some market share to be assigned to a more expensive option, thereby, incorporating some of the subsidy (see explanation below Eq. (6)). Finally, in reality other policy incentives have been used, such as tax credits or rebate programs that do not show up in the reported subsidy [6].

\subsection{Scenario}

\subsubsection{Results at global scale}

In the baseline scenario (SSP2), combined PV (utility-scale PV and rooftop PV) as a share of the total electricity production increased in 2050 by $80 \%$ (from $6 \%$ to $11 \%$ ) when rooftop PV was included (SSP2_RT) (Figs. 6 and 7). The combined PV capacity in 2050 was projected to be $3500 \mathrm{GW}: 1700 \mathrm{GW}$ more than in the scenario that excluded rooftop PV. This is a result of the combined learning of utilityscale and rooftop PV, showing the importance of rooftop PV for understanding overall PV dynamics. In terms of cost, this added capacity drives learning effects that decreased PV capital costs by 4-8\% between 2020 and 2030. Although there is a net increase in the use of renewables, rooftop PV takes some market share from other renewables. In comparison to a baseline scenario without rooftop PV (SSP2), utility-scale PV's electricity production decreased by $90 \mathrm{TWh}^{-1}(-3 \%)$ and wind decreased by $600 \mathrm{TWh} \mathrm{y}^{-1}(-11 \%)$. Of the fossil-fuel technologies, coal

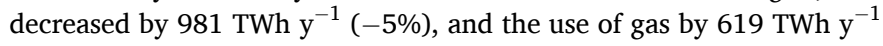
(9\%).

The role of rooftop PV depends on policy assumptions, as shown in Fig. 7. The rooftop PV policy scenario (SSP2_RTPol), shows that netmetering can increase the combined PV share by $180 \%$ compared to SSP2_RT, lifting the combined PV share from $6 \%$ to $17 \%$ of the total electricity production. In the climate policy scenario (SSP2_ClimPol) the combined PV share in 2050 increased by $125 \%$ when rooftop PV was included (SSP2_RTPol_ClimPol) (from $8 \%$ to $18 \%$ of the total electricity production). The calculated combined PV capacity in 2050 is $6000 \mathrm{GW}$ : $4000 \mathrm{GW}$ more than in the scenario that excludes rooftop PV. In terms of cost, this results in a $4-10 \%$ cost decreased between 2020 and 2030. As occurred in the baseline scenario, rooftop PV caused a net increase of the use of renewables but took away market shares from other technologies. While in the baseline scenario the use of coal and gas were reduced; the inclusion of rooftop PV in the climate policy scenario (SSP2_RTPol_ClimPol) affects mostly other renewables: utility-scale PV $(-21 \%)$, onshore wind $(-7 \%)$, offshore wind $(-10 \%)$, nuclear $(-10 \%)$ and carbon capture and storage (CCS) from coal $(-18 \%)$ and gas $(-18 \%)$. The

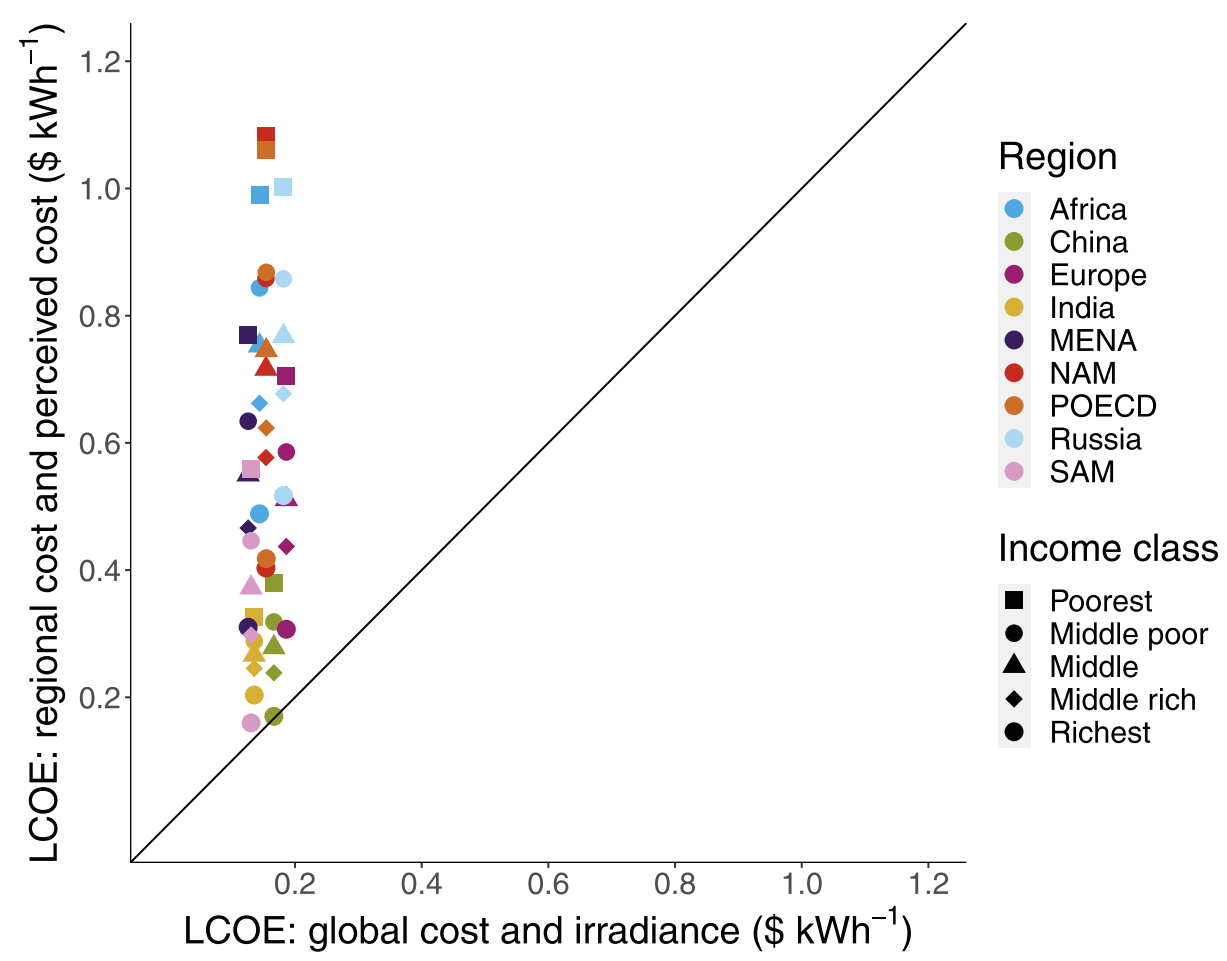

Fig. 8. The rooftop PV LCOE based on just irradiance (x-axis) versus the LCOE based on perceived costs, regional capital cost, and irradiance (y-axis). 


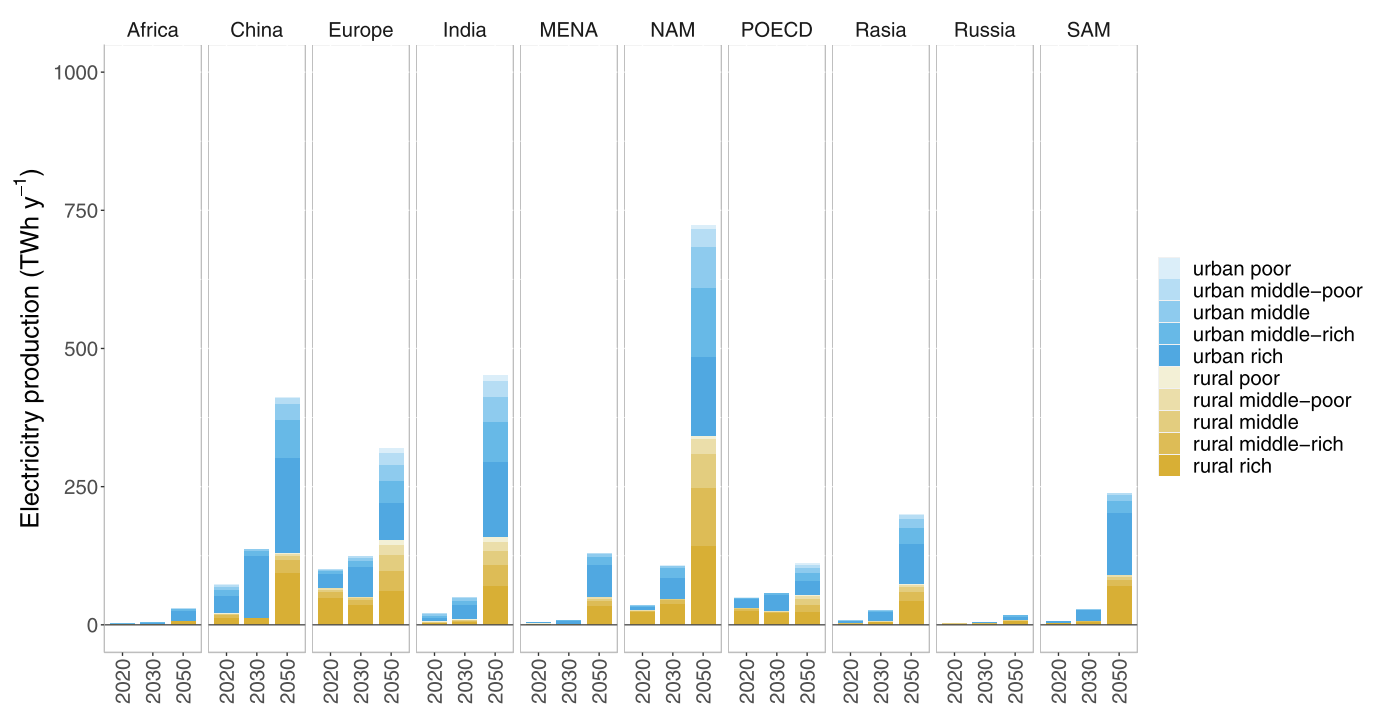

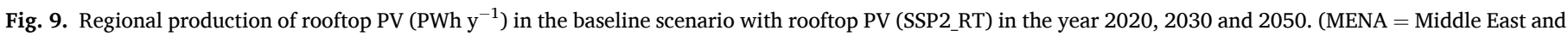
north Africa, NAM = North America, POECD = Pacific OECD, RAsia = Rest of Asia (Asia excluding India and China), SAM = South America).
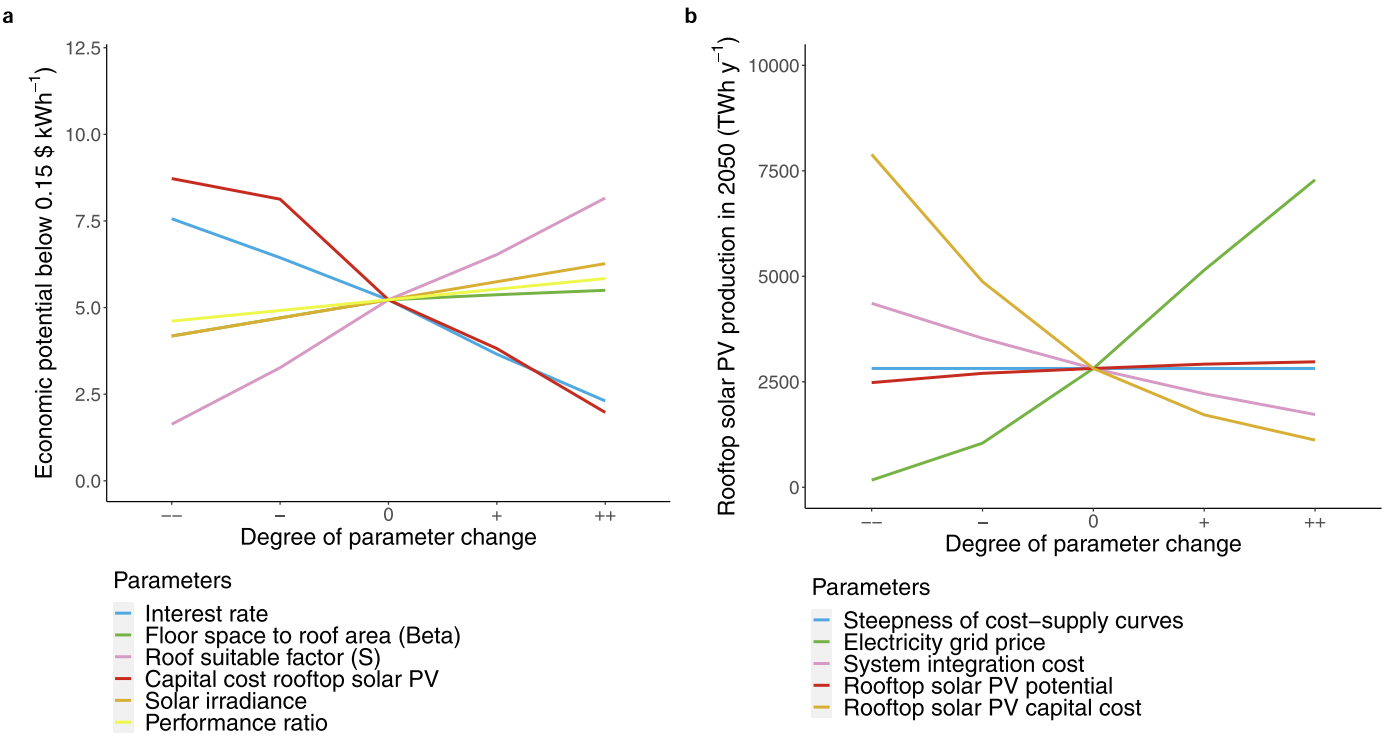

Fig. 10. Sensitivity analyses. a, Sensitivity runs on the economic potential $\left(<0.15 \$ \mathrm{kWh}^{-1}\right)$. See Appendix Table A5 for the defined degree of parameter change. b, Sensitivity runs with the IMAGE model on the rooftop PV production in $2030\left(\mathrm{TWh}^{-1}\right)$. See Appendix Table A6 for defined degree of parameter change.

use of bio-energy combined cycle increased with $30 \%$, however, to compensate for the loss of stability in the electricity system. In technical terms: to adjust for the loss of available residual full load hours and system reserve requirements. Market penetration is further explored in the sensitivity analyses in the discussion section (see Fig. 10).

\subsubsection{Results at regional scale}

There are various factors that influence regional differences in the deployment of rooftop PV.

a) Irradiance. Some regions have higher irradiance levels leading to a higher potential and lower costs (see Fig. 4).

b) Regional capital costs for rooftop PV vary significantly, from 1460 \$ $\mathrm{kW}^{-1}$ in India to $3480 \$ \mathrm{~kW}^{-1}$ in the US (Table 1). Although these capital costs will likely converge in the future through learning and trade, they have a distinct effect on the short-term deployment of rooftop PV.

c) Upfront investment is required to install rooftop PV systems. These investments are perceived differently for different income groups: a high-income household perceives it at lower costs than a low-income household. This is expressed by the consumer discount rates (see Section 2.2.3).

d) Taxes and subsidies, that differ per technology and per region.

e) Costs of competing technologies, that also differ per region.

\section{Regional differences in rooftop PV}

We can compare the impact of the physical factors (a) to the other factors (b-d) that determine rooftop PV costs, by calculating the costs based on irradiance only to the final perceived prices by the households per region based on the consumer discount rates and the regional capital 
cost, as used in the IMAGE model (Fig. $8^{1}$ ). What Fig. 8 clearly shows is that the spread caused by irradiance alone (horizontal) is smaller than the spread caused by the regional capital cost and the perceived costs (vertical). Solar irradiance causes approximately $10 \%$ of the cost variance; the other two factors $90 \%$.

Prices of alternative options.

Electricity prices are the benchmark rooftop PV prices are compared to. The electricity price is the average price of the whole electricity market, with added taxes, T\&D costs, and subsidies. In the IMAGE model this price is based on the dynamics of 28 different combinations of renewable, nuclear, fossil-fuel, and bio-energy options. The regional prices differ between 0.10 and $0.20 \$ \mathrm{kWh}^{-1}$ which is consistent with prices reported in literature [30]. Comparing western Europe with the Middle East, for example, illustrates how the benchmark effect works. In western Europe, rooftop PV $\left(0.24 \$ \mathrm{kWh}^{-1}\right)$ is approximately $0.04 \$$ $\mathrm{kWh}^{-1}$ more expensive than the whole-sale electricity price (around $0.20 \$ \mathrm{kWh}^{-1}$ ). In the Middle East, however, it is $0.06 \$ \mathrm{kWh}^{-1}$ more expensive, despite a lower rooftop PV price of around $0.16 \$ \mathrm{kWh}^{-1}$. Here cheap fossil-fuels, low taxes, and high subsidies result in a wholesale electricity price that is half of the European price. The result is thus a lower deployment of rooftop PV in the Middle East compared to western Europe (see Fig. 9).

\section{Deployment per region}

The three regional factors (capital cost, perceived cost, and electricity prices) drive the deployment of rooftop PV (Fig. 9). The regions with the highest deployment of rooftop PV in 2050 are North America (27\% of global rooftop PV capacity, most from the US), India (with 17\%), and Europe (with 12\%). The results from the US are similar to the results found by Drury [41], whom presents a lower estimate of 30GW in 2030 without incentives and a higher estimate of 270GW with incentives. Our results for the US in 2030 range from 65 GW (without incentives) to $220 \mathrm{GW}$ (with net-metering incentives). The reason the US shows higher deployment than China, for example, even though China has a higher technical potential (see Fig. 3), is because the US have a larger share of the population in high-income groups in combination with higher whole-sale electricity prices. The reason Europe deploys less rooftop PV than the US, despite similar technical potential and electricity prices, is because a larger share of the US cost-supply curve is in the cost competitive range.

The technical potential (i.e. the available roof area) can become a limiting factor in some regions. In several regions, the deployment in the model by 2050 is more than half the technical potential. North America, for instance, uses 60\%. Globally, in the SSP2 baseline, 25\% of the 2015 rooftop PV technical potential is utilized by 2050. Interestingly, some regions exceed their 2015 rooftop PV potential. In 2015, India has a potential of about $1500 \mathrm{TWh} \mathrm{y}^{-1}$ but, by 2100 , produces almost 5000 $\mathrm{TWh}^{-1}$; more than $300 \%$ of its 2015 potential. This is an effect of the growth in roof area driven by population and GDP growth. This effect is seen in most developing regions, including Africa, Asia, and South America.

\section{Discussion}

This study estimates global technical and economic rooftop PV potential and performs a long-term scenario assessment with a broad range of regional factors, going beyond earlier scenario analysis that focused mainly on utility-scale PV. The results show that current global rooftop potential is 1.5 times the residential electricity demand. The market penetration of rooftop solar PV is much more dependent on socioeconomic and policy factors than on the biophysical potential. Several aspects require further discussion.

The first aspect concerns the lack of data in the roof area estimates. Census data on buildings, for example, were found for a selected number of countries only; mainly developed countries. The same holds true for regional differentiation of the rooftop suitability factor $(0.32, \mathrm{~S}$ in Eq. (2)), and historical data to develop dynamic floor-space-to-roof-area coefficients ( $\beta$ in Eq. (2)). As regions develop and construction skills improve, houses are built higher, and coefficients will likely become lower. Especially for developing regions, this needs to be included to avoid an overestimation of the technical potential. A second point of discussion is that this study considers residential buildings but neglects buildings from the service sector. The data and parameters we used to calculate floor space to roof area could not be found for the services sector. Including roofs from the services sector, however, might increase the potential significantly, as also shown by studies that did include the service sector roof area Gagnon [18,36]. The third point of discussion concerns the use of an IAM to study rooftop PV. IAMs are designed to assess long-term trends and are, therefore, less well equipped for shortterm effects in specific regions.

To assess the sensitivity of key parameters we performed two analyses. In the first, assumptions regarding the economic potential were tested (Fig. 10a), and, in the second analysis, model and scenario assumptions were tested (Fig. 10b). Four parameters cause the economic potential to increase when parameters increase: the floor-space-to-roofarea coefficients ( $\beta$ in Eq. (2)), the roof area suitable factor (S in Eq. (2)), the performance ratio (PR in Eq. (1)), and the solar irradiance. The interest rate and capital costs have an opposite effect. In the scenario sensitivity, the effects on the rooftop PV production in 2050 caused by the cost-supple curve and the maximum potential were not influential, although this might be different later in the century when developing regions dominate the PV deployment. The three factors that are influential in 2050 are: the system integration cost, the PV capital cost, and the whole-sale electricity price. The first component, refers to the costs necessary to integrated intermittent supply from solar PV in the electricity system, such as battery storage or back-up capacity. This cost component becomes, by 2050, influential for the adoption of rooftop PV; halving these cost could add almost $50 \%$ of rooftop PV production. Results from a separate analyses done for the year 2030, show a much lower sensitivity, indicating that it's influence grows over time as higher shares of intermittent supply penetrate the system. The latter two factors (PV capital cost and whole-sale electricity price) are part of the new household decision and show non-linear behaviour, caused by the multi-nominal logit equation (Eq. (6)). Halving the PV capital cost could lead to a three-fold increase of the rooftop PV production in 2050 but, interestingly, so can a doubling of the electricity price.

\section{Conclusion and policy implications}

This study estimates global technical and economic rooftop photovoltaic potential and performs a long-term scenario assessment with a broad range of regional factors. Physical information on solar irradiation and roof area was combined with cost data to derive regional cost-supply curves that were inserted into the IMAGE Integrated Assessment Model.

\footnotetext{
${ }^{1}$ For the purpose of this analyses a global capital cost of $1600 \$ \mathrm{~kW}^{-1}$ is assumed [6] IRENA. IRENA Cost and Competitiveness Indicators: Rooftop Solar PV. Abu Dhabi: International Renewable Energy Agency; 2017. For regional capital cost see Table 1 and for perceived costs Eq. (5) on CDRs.
} 
The possibility per household to decide for rooftop photovoltaic was modelled in IMAGE through a new investment decision that compares the whole-sale electricity price with the price of rooftop photovoltaic. This decision was implemented with region specific characteristics, including factors such as income levels, retail electricity prices, taxes, and investment costs. Based on our analysis, we draw the following conclusions.

The rooftop photovoltaic cost-supply curves show a potential of 8.3 $\mathrm{PWh}^{-1}$ in 2015 on a global suitable roof area of 36 billion $\mathrm{m}^{2}$ and cost levels of $0.09-0.5 \$ \mathrm{kWh}^{-1}$. The total potential of $8.3 \mathrm{PWh} \mathrm{y}^{-1}$ is roughly 1.5 times the 2015 global residential electricity demand. The potential and costs estimated in this study are consistent with those reported by literature.

Rooftop photovoltaic key driver in photovoltaic market; historical behaviour well simulated. In IMAGE, the cost-supply curves were linked with the residential module and the electricity module to represent household investment behaviour on rooftop photovoltaic. Using internal model simulations, historical feed-in tariff subsidies and historical capacity data were mimicked closely.

Rooftop photovoltaic has been important in the past and will likely remain so in the future. We used the IMAGE model to compare two scenarios-one in which we simulated the availability of rooftop photovoltaic and one in which we did not. We found that the share of photovoltaic in the total electricity production increases by $80 \%$ in 2050 in the scenario that includes rooftop photovoltaic. Deployment is highest in Europe and the US, regions with large roof areas and a large share of the population with high income. Despite lower roof area per capita, China and India can also see high deployment due to large population and rising income levels. In the analysis, rooftop photovoltaic drives down the costs of overall photovoltaic through learning, decreasing photovoltaic capital costs further by $4-10 \%$ between 2020 and 2030. In a climate policy scenario with rooftop photovoltaic, total photovoltaic production increased $150 \%$ compared to the scenario without rooftop photovoltaic.

Low-irradiation western Europe better than high-irradiation Middle East. Socio-economic and policy factors are more important for nearterm deployment of rooftop photovoltaic than physical factors. The deployment of rooftop photovoltaic depends on the perceived costs for consumers versus other available options. Differences in income levels, whole-sale electricity prices, and investment costs dominate regional deployment.

The analyses in this paper shows that the deployment of rooftop PV is regionally depended. Some of the regional differences, however, can be elevated through global market measures. PV panel prices, for example, differ per region, which global trade without barriers could reduce. Trade, and other forms of economic collaboration, could also alleviate poverty levels lifting more people into high-income levels with which they could afford to invest in rooftop PV systems. Regional policy measures, such as subsidies, must be carefully fitted to the regional context, and must take into account existing energy prices, tax levels, and in particular income levels and perceived cost (as opposed to real cost) to be effective. This regional context is, however, not static and changes continuously. Policy measures to incentivise rooftop PV are, therefore, well advised to be adaptable over time.

Data availability

The data that support the plots within this paper and other findings of this study are available from the corresponding author upon reasonable request.

\section{CRediT authorship contribution statement}

David E.H.J. Gernaat: Conceptualization, Data curation, Formal analysis, Investigation, Methodology, Software, Supervision, Validation, Visualization, Writing - original draft, Writing - review \& editing. Harmen-Sytze Boer: Methodology, Software, Validation, Visualization, Writing - original draft, Writing - review \& editing. Louise C. Dammeier: Data curation, Formal analysis, Investigation, Methodology, Software, Writing - original draft. Detlef P. Vuuren: Conceptualization, Methodology, Supervision, Validation, Writing - original draft, Writing review \& editing.

\section{Declaration of Competing Interest}

The authors declare that they have no known competing financial interests or personal relationships that could have appeared to influence the work reported in this paper.

\section{Acknowledgements}

The research leading to these results has received funding from FP7/ 2007-2013 financial support under grant agreement number 308329 (ADVANCE).

\section{Appendix A}

\section{Text A1: Description of the electricity module}

The electricity module described by de Boer [26] simulates generation of electricity by various technologies. These technologies compete for a share in investments based on technology costs per amount of generated electricity. These technology costs, in turn, change over time, as it is subject to technology development and depletion effects. TIMER's electricity module describes 28 different combinations of renewable, nuclear, fossil fuel and bio-energy electricity technologies. For each fuel (coal, oil, natural gas, bio-fuel), the model distinguishes a conventional technology, gasification and/or combined cycle technology, combined-heat-and-power (CHP) technology, carbon capture and storage (CCS) technology and CHP combined with CCS technology.

LCOEs are determined per load band, each load band having a different load factor based on the shape of the (residual) load duration curve. The LCOE contains integration costs like backup costs, storage costs and the costs of curtailments. In that way, investments account for expected electricity that will be produced by a technology [26]. After the investment decisions, a power system operation algorithm describes the use of the technologies for power generation. This is done based on a merit order strategy, based on low operational costs and the characteristics of the different technologies in various load bands as described by de Boer [26].

\section{Text A2: Description of the Shared Socio-economic Pathways (SSPs)}

The SSP framework defines five storylines that differ in the degree of challenge for mitigation and in the degree of challenge for adaptation [42]. Three storylines are used for analyses [12]. The SSP1 scenario depicts a world that aims for green growth and sustainable development. Climate policy is not implemented directly, but through technological developments for a higher energy efficiency and a better use of 
Table A1

Census data on floors.

\begin{tabular}{|c|c|c|c|c|c|c|c|c|c|c|}
\hline \# floors per household/Country & 1 & 2 & 3 & 4 & 5 & 6 & 7 & 8 & 9 & 10 \\
\hline Qatar $^{1}$ & $38.6 \%$ & $41.6 \%$ & $7.7 \%$ & $2.5 \%$ & $3.1 \%$ & $2.1 \%$ & $1.5 \%$ & $1.2 \%$ & $0.9 \%$ & $0.8 \%$ \\
\hline $\mathrm{US}^{2}$ & $19.4 \%$ & $20.0 \%$ & $38.0 \%$ & $4.8 \%$ & $4.8 \%$ & $4.8 \%$ & $8.3 \%$ & $0.0 \%$ & $0.0 \%$ & $0.0 \%$ \\
\hline Hungary $^{3}$ & $95.7 \%$ & $4.3 \%$ & $0.0 \%$ & $0.0 \%$ & $0.0 \%$ & $0.0 \%$ & $0.0 \%$ & $0.0 \%$ & $0.0 \%$ & $0.0 \%$ \\
\hline Australia $^{4}$ & $78.4 \%$ & $2.8 \%$ & $8.8 \%$ & $10.0 \%$ & $0.0 \%$ & $0.0 \%$ & $0.0 \%$ & $0.0 \%$ & $0.0 \%$ & $0.0 \%$ \\
\hline Albania $^{5}$ & $74.4 \%$ & $8.8 \%$ & $5.6 \%$ & $3.1 \%$ & $2.0 \%$ & $2.2 \%$ & $1.5 \%$ & $1.1 \%$ & $0.9 \%$ & $0.6 \%$ \\
\hline Japan $^{6}$ & $6.4 \%$ & $21.3 \%$ & $12.4 \%$ & $13.7 \%$ & $3.4 \%$ & $4.1 \%$ & $4.8 \%$ & $5.5 \%$ & $6.2 \%$ & $22.3 \%$ \\
\hline Jordan $^{7}$ & $39.6 \%$ & $21.6 \%$ & $21.2 \%$ & $10.7 \%$ & $5.0 \%$ & $1.3 \%$ & $0.4 \%$ & $0.1 \%$ & $0.0 \%$ & $0.0 \%$ \\
\hline Finland $^{8}$ & $60.0 \%$ & $25.1 \%$ & $7.6 \%$ & $3.0 \%$ & $1.7 \%$ & $1.0 \%$ & $0.7 \%$ & $0.5 \%$ & $0.3 \%$ & $0.2 \%$ \\
\hline Greece $^{9}$ & $35.6 \%$ & $25.4 \%$ & $17.9 \%$ & $8.0 \%$ & $5.4 \%$ & $4.7 \%$ & $3.1 \%$ & $0.0 \%$ & $0.0 \%$ & $0.0 \%$ \\
\hline Switzerland $^{10}$ & $2.4 \%$ & $14.6 \%$ & $37.3 \%$ & $20.7 \%$ & $11.0 \%$ & $6.1 \%$ & $3.8 \%$ & $2.0 \%$ & $1.0 \%$ & $1.2 \%$ \\
\hline Czech Republic ${ }^{11}$ & $31.7 \%$ & $31.7 \%$ & $9.6 \%$ & $12.8 \%$ & $14.3 \%$ & $0.0 \%$ & $0.0 \%$ & $0.0 \%$ & $0.0 \%$ & $0.0 \%$ \\
\hline Bahrain $^{12}$ & $38.3 \%$ & $42.1 \%$ & $12.1 \%$ & $3.0 \%$ & $1.0 \%$ & $0.4 \%$ & $3.1 \%$ & $0.0 \%$ & $0.0 \%$ & $0.0 \%$ \\
\hline Cape Verde & $31.7 \%$ & $31.7 \%$ & $9.6 \%$ & $12,8 \%$ & $14.3 \%$ & $0.0 \%$ & $0.0 \%$ & $0.0 \%$ & $0.0 \%$ & $0.0 \%$ \\
\hline Turkey $^{13}$ & $6.1 \%$ & $5.9 \%$ & $10.8 \%$ & $14.3 \%$ & $20.8 \%$ & $42.1 \%$ & $0.0 \%$ & $0.0 \%$ & $0.0 \%$ & $0.0 \%$ \\
\hline Mauritius $^{14}$ & $52.4 \%$ & $38.4 \%$ & $7.2 \%$ & $1.3 \%$ & $0.2 \%$ & $0.1 \%$ & $0.5 \%$ & $0.0 \%$ & $0.0 \%$ & $0.0 \%$ \\
\hline Germany $1971^{15}$ & $15.3 \%$ & $37.3 \%$ & $21.0 \%$ & $16.2 \%$ & $6.9 \%$ & $0.4 \%$ & $0.2 \%$ & $0.1 \%$ & $0.0 \%$ & $1.2 \%$ \\
\hline Germany $1981^{16}$ & $15.6 \%$ & $32.7 \%$ & $17.6 \%$ & $15.0 \%$ & $12.7 \%$ & $2.2 \%$ & $1.5 \%$ & $1.0 \%$ & $0.5 \%$ & $1.2 \%$ \\
\hline Indonesia $1990^{17}$ & $94.8 \%$ & $5.2 \%$ & $0.0 \%$ & $0.0 \%$ & $0.0 \%$ & $0.0 \%$ & $0.0 \%$ & $0.0 \%$ & $0.0 \%$ & $0.0 \%$ \\
\hline Indonesia $1995^{18}$ & $94.5 \%$ & $5.5 \%$ & $0.0 \%$ & $0.0 \%$ & $0.0 \%$ & $0.0 \%$ & $0.0 \%$ & $0.0 \%$ & $0.0 \%$ & $0.0 \%$ \\
\hline Kyrgyz Republic ${ }^{19}$ & $77.2 \%$ & $3.5 \%$ & $10.0 \%$ & $5.0 \%$ & $1.4 \%$ & $1.2 \%$ & $0.8 \%$ & $0.5 \%$ & $0.4 \%$ & $0.3 \%$ \\
\hline Spain $1991^{20}$ & $14.7 \%$ & $21.0 \%$ & $7.7 \%$ & $9.7 \%$ & $12.7 \%$ & $9.0 \%$ & $5.9 \%$ & $5.9 \%$ & $4.3 \%$ & $9.2 \%$ \\
\hline Spain $2011^{21}$ & $14.7 \%$ & $34.4 \%$ & $13.3 \%$ & $10.9 \%$ & $11.4 \%$ & $7.6 \%$ & $4.9 \%$ & $4.9 \%$ & $2.5 \%$ & $5.7 \%$ \\
\hline
\end{tabular}

The percentage of household with 1-10 floors per country.

1 [43] Quatar Ministry of Development Planning and Statistics. Qatar 2010 Population and Housing Census 2010.

2 [44] EIA. Residential Energy Consumtion survey data. 2009.

3 [45] Hungarian Central Statistical Office. Population census. Budapest, Hungary. 2011.

4 [46] Australian bureau of Statistics. Census of Population and housing 2001.

5 [47] INSTAT. Census of population and housing. Institute of Statistics; 2011.

6 [48] Statistics of Japan (e-Stat). Housing and Land Survey. 2014.

7 [49] Department of Statistics Jordan. Population and Housing Census. 2004.

8 [50] Statistics Finland. Buildings and Free-time Residences. 2014.

9 [51] Hellenic Statistical Authority. Population-Housing Census. 2010.

10 [52] Federal Statistical Office. Census building and housing. 2013.

11 [53] Český statistický úřad. Veřejná databáze ČSÚ - Housing stock. 2011.

12 [54] Central Informatics Organisation. Census building and housing. 2010.

13 [55] Turkish Statistical Housing Census. Population and Housing Censuses. 2011.

14 [56] Central Statistics Office Mauritius. 2011 Housing Census. Port Louis2011.

15 [57] Central State Office for Statistics Germany. Germany - Census of Population, Occupation, Dwellings and Buildings 1971 - IPUMS Subset. 1971.

16 [58] Central State Office for Statistics Germany. Germany - Census of Population, Occupation, Dwellings and Buildings 1981 - IPUMS Subset. 1981.

17 [59] Central Bureau of Statistics Indonesia. Indonesia - Population Census 1990 - IPUMS Subset. 1990.

18 [60] Central Bureau of Statistics Indonesia. Indonesia - Population Census 1995 - IPUMS Subset. 1995.

19 [61] National Statistical Committee of the Kyrgyz Republic. Kyrgyz Republic - Census of Population and Housing of the Kyrgyz Republic 2009 - IPUMS Subset. 2009.

${ }^{20}$ [62] Instituto Nacional de Estadisticas (INE). Spain - Census of Population and Housing 1991 - IPUMS Subset. 1991.

21 [63] Instituto Nacional de Estadisticas (INE). Spain - Census of Population and Housing 2011 - IPUMS Subset. 2011. 
Table A2

Floor space to roof area Beta.

\begin{tabular}{|c|c|c|c|c|c|c|}
\hline IMAGE Region & Countries with statistical data & Year of statistical data & Floor space $^{1}$ & Households & Beta & Roof area \\
\hline Middle East & Qatar & 2010 & 19.6 & $51,110,390$ & 0.64 & 12.54 \\
\hline US & US & 2009 & 53.24 & $89,840,570$ & 0.46 & 24.49 \\
\hline Central Europe & Hungary & 2011 & 32.82 & $43,699,870$ & 0.98 & 32.16 \\
\hline Oceania & Australia & 2001 & 47.71 & $9,854,651$ & 0.85 & 40.56 \\
\hline Central Europe & Albania & 2011 & 32.82 & $43,699,870$ & 0.83 & 27.24 \\
\hline Japan & Japan & 2014 & 33.14 & $49,569,600$ & 0.3 & 9.94 \\
\hline Middle East & Jordan & 2005 & 17.8 & $41,755,040$ & 0.61 & 10.86 \\
\hline Western Europe & Finland & 2014 & 43.74 & $1.74 \mathrm{E}+08$ & 0.77 & 33.68 \\
\hline Western Europe & Greece & 2010 & 43.21 & $1.67 \mathrm{E}+08$ & 0.59 & 25.5 \\
\hline Western Europe & Switzerland & 2013 & 43.63 & $1.72 \mathrm{E}+08$ & 0.31 & 13.53 \\
\hline Central Europe & Czech Republic & 2011 & 32.82 & $43,699,870$ & 0.57 & 18.71 \\
\hline Middle East & Bahrain & 2001 & 17.29 & $35,710,320$ & 0.65 & 11.24 \\
\hline Western Africa & Cape Verde & 2010 & 9.96 & $67,852,710$ & 0.68 & 6.77 \\
\hline Turkey & Turkey & 2011 & 31.03 & $19,620,374$ & 0.27 & 8.38 \\
\hline Eastern Africa & Mauritius & 2010 & 6.66 & $52,581,010$ & 0.74 & 4.93 \\
\hline Western Europe & Germany & 1971 & 31.09 & $87,486,580$ & 0.47 & 14.61 \\
\hline Western Europe & Germany & 1981 & 35.18 & $1.3 \mathrm{E}+08$ & 0.45 & 15.83 \\
\hline Indonesia & Indonesia & 1990 & 10.63 & $35,576,540$ & 0.97 & 10.31 \\
\hline Indonesia & Indonesia & 1995 & 11.23 & $43,714,370$ & 0.97 & 10.89 \\
\hline Central Asia & Kyrgyz Republic & 2009 & 17.4 & $20,857,767$ & 0.84 & 14.62 \\
\hline Western Europe & Spain & 1991 & 39.13 & $1.59 \mathrm{E}+08$ & 0.37 & 14.48 \\
\hline Western Europe & Spain & 2011 & 43.4 & $1.69 \mathrm{E}+08$ & 0.45 & 19.53 \\
\hline World & World & Weighted Average & 34.91 & $1.71 \mathrm{E}+09$ & 0.56 & 19.55 \\
\hline
\end{tabular}

${ }^{1}$ IMAGE household data calculated with Eq. (2).

Table A3

Floor space to roof area coefficient ( $\beta$ in Eq. (2)) allocated to IMAGE regions.

\begin{tabular}{|c|c|c|c|}
\hline IMAGE Regions & Available data & Allocated region & Beta \\
\hline Canada & - & US & 0.46 \\
\hline US & US & US & 0.46 \\
\hline Mexico & - & Average $^{1}$ & 0.56 \\
\hline Rest Central- America & - & Average $^{1}$ & 0.56 \\
\hline Brazil & - & Average $^{1}$ & 0.56 \\
\hline Rest South- America & - & Average $^{1}$ & 0.56 \\
\hline Northern-Africa & - & Middle-East $^{1}$ & 0.63 \\
\hline Western-Africa & Western-Africa & Western-Africa & 0.68 \\
\hline Eastern-Africa & Eastern-Africa & Eastern-Africa & 0.74 \\
\hline Southern-Africa & - & Average $^{1}$ & 0.56 \\
\hline Western-Europe & Western-Europe & Western-Europe $^{1}$ & 0.50 \\
\hline Central-Europe & Central-Europe & Central-Europe $^{1}$ & 0.79 \\
\hline Turkey & Turkey & Turkey & 0.27 \\
\hline Ukraine + & - & Central-Europe $^{1}$ & 0.79 \\
\hline Asia-Stan & Central-Asia & Central-Asia & 0.84 \\
\hline Russia + & - & Central-Asia & 0.84 \\
\hline Middle-East & Middle-East & Middle-East $^{1}$ & 0.63 \\
\hline India + & - & Indonesia & 0.97 \\
\hline Korea & - & Japan & 0.30 \\
\hline China + & - & Average $^{1}$ & 0.56 \\
\hline Southeastern Asia & - & Indonesia & 0.97 \\
\hline Indonesia + & Indonesia & Indonesia & 0.97 \\
\hline Japan & Japan & Japan & 0.30 \\
\hline Oceania & Oceania & Oceania & 0.85 \\
\hline Rest S.Asia & - & Indonesia & 0.97 \\
\hline Rest S.Africa & - & Average $^{1}$ & 0.56 \\
\hline Average & & Average $^{1}$ & 0.56 \\
\hline
\end{tabular}

\footnotetext{
${ }^{1}$ Household weighted average of the available countries.
} 
Table A4

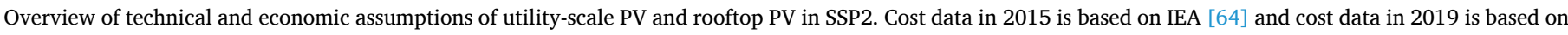
IEA [20].

\begin{tabular}{|c|c|c|c|c|c|c|c|c|c|c|c|}
\hline \multirow[b]{2}{*}{ Region } & \multirow[b]{2}{*}{ Technology } & \multirow[b]{2}{*}{ Learning rate } & \multicolumn{2}{|c|}{ Lifetime (years) } & \multicolumn{2}{|c|}{ OPEX $\left(\$ \mathrm{~kW}^{-1}(2015)\right)$} & \multicolumn{5}{|c|}{ CAPEX $\left(\$ \mathrm{~kW}^{-1}(2015)\right)$} \\
\hline & & & Technical & Economic & O\&M fixed & O\&M variable & 2015 & 2020 & 2030 & 2040 & 2050 \\
\hline \multirow[t]{2}{*}{ Western Europe } & Utility-scale PV & 0.2 & 25 & 20 & 17 & 0 & 1320 & 974 & 837 & 706 & 591 \\
\hline & Rooftop PV & 0.2 & 25 & 20 & 20 & 0 & 1600 & 1293 & 1128 & 946 & 790 \\
\hline \multirow[t]{2}{*}{ Central Europe } & Utility-scale PV & 0.2 & 25 & 20 & 17 & 0 & 1320 & 975 & 838 & 707 & 592 \\
\hline & Rooftop PV & 0.2 & 25 & 20 & 20 & 0 & 1600 & 1294 & 1130 & 947 & 791 \\
\hline \multirow[t]{2}{*}{ US } & Utility-scale PV & 0.2 & 25 & 20 & 17 & 0 & 2220 & 1315 & 950 & 701 & 588 \\
\hline & Rooftop PV & 0.2 & 25 & 20 & 20 & 0 & 3480 & 2867 & 1689 & 940 & 786 \\
\hline \multirow[t]{2}{*}{ Canada } & Utility-scale PV & 0.2 & 25 & 20 & 17 & 0 & 2220 & 1317 & 956 & 707 & 592 \\
\hline & Rooftop PV & 0.2 & 25 & 20 & 20 & 0 & 3480 & 2870 & 1698 & 947 & 791 \\
\hline \multirow[t]{2}{*}{ Oceania } & Utility-scale PV & 0.2 & 25 & 20 & 17 & 0 & 2220 & 1316 & 955 & 707 & 592 \\
\hline & Rooftop PV & 0.2 & 25 & 20 & 20 & 0 & 3480 & 2869 & 1697 & 947 & 791 \\
\hline \multirow[t]{2}{*}{ Japan } & Utility-scale PV & 0.2 & 25 & 20 & 17 & 0 & 2020 & 1420 & 991 & 707 & 592 \\
\hline & Rooftop PV & 0.2 & 25 & 20 & 20 & 0 & 2880 & 1930 & 1352 & 947 & 791 \\
\hline \multirow[t]{2}{*}{ Korea } & Utility-scale PV & 0.2 & 25 & 20 & 17 & 0 & 2020 & 1421 & 992 & 707 & 592 \\
\hline & Rooftop PV & 0.2 & 25 & 20 & 20 & 0 & 2880 & 1931 & 1353 & 947 & 791 \\
\hline \multirow[t]{2}{*}{ Russia } & Utility-scale PV & 0.2 & 25 & 20 & 17 & 0 & 2580 & 1640 & 1067 & 707 & 592 \\
\hline & Rooftop PV & 0.2 & 25 & 20 & 20 & 0 & 3480 & 2195 & 1444 & 947 & 791 \\
\hline \multirow[t]{2}{*}{ Turkey } & Utility-scale PV & 0.2 & 25 & 20 & 17 & 0 & 2580 & 1640 & 1067 & 707 & 592 \\
\hline & Rooftop PV & 0.2 & 25 & 20 & 20 & 0 & 3480 & 2194 & 1444 & 947 & 791 \\
\hline \multirow[t]{2}{*}{ Ukraine } & Utility-scale PV & 0.2 & 25 & 20 & 17 & 0 & 2580 & 1640 & 1067 & 707 & 592 \\
\hline & Rooftop PV & 0.2 & 25 & 20 & 20 & 0 & 3480 & 2194 & 1444 & 947 & 791 \\
\hline Central Asia & Utility-scale PV & 0.2 & 25 & 20 & 17 & 0 & 2580 & 1640 & 1067 & 707 & 592 \\
\hline & Rooftop PV & 0.2 & 25 & 20 & 20 & 0 & 3480 & 2195 & 1444 & 948 & 791 \\
\hline China + & Utility-scale PV & 0.2 & 25 & 20 & 17 & 0 & 1360 & 790 & 684 & 582 & 492 \\
\hline & Rooftop PV & 0.2 & 25 & 20 & 20 & 0 & 1480 & 1005 & 883 & 752 & 638 \\
\hline Southeast Asia & Utility-scale PV & 0.2 & 25 & 20 & 17 & 0 & 1360 & 792 & 686 & 583 & 493 \\
\hline & Rooftop PV & 0.2 & 25 & 20 & 20 & 0 & 1480 & 1008 & 885 & 753 & 640 \\
\hline Indonesia & Utility-scale PV & 0.2 & 25 & 20 & 17 & 0 & 1360 & 793 & 686 & 583 & 494 \\
\hline & Rooftop PV & 0.2 & 25 & 20 & 20 & 0 & 1480 & 1008 & 885 & 753 & 640 \\
\hline Rest of South Asia & Utility-scale PV & 0.2 & 25 & 20 & 17 & 0 & 1360 & 793 & 686 & 584 & 494 \\
\hline & Rooftop PV & 0.2 & 25 & 20 & 20 & 0 & 1480 & 1008 & 886 & 754 & 640 \\
\hline India & Utility-scale PV & 0.2 & 25 & 20 & 17 & 0 & 1340 & 706 & 613 & 524 & 447 \\
\hline & Rooftop PV & 0.2 & 25 & 20 & 20 & 0 & 1460 & 801 & 706 & 612 & 531 \\
\hline Middle East & Utility-scale PV & 0.2 & 25 & 20 & 17 & 0 & 2360 & 1961 & 1178 & 707 & 591 \\
\hline & Rooftop PV & 0.2 & 25 & 20 & 20 & 0 & 3000 & 2545 & 1566 & 947 & 791 \\
\hline North Africa & Utility-scale PV & 0.2 & 25 & 20 & 17 & 0 & 2400 & 1625 & 1062 & 707 & 592 \\
\hline & Rooftop PV & 0.2 & 25 & 20 & 20 & 0 & 2840 & 1974 & 1364 & 947 & 791 \\
\hline West Africa & Utility-scale PV & 0.2 & 25 & 20 & 17 & 0 & 2400 & 1626 & 1062 & 707 & 592 \\
\hline & Rooftop PV & 0.2 & 25 & 20 & 20 & 0 & 2840 & 1974 & 1364 & 947 & 791 \\
\hline East Africa & Utility-scale PV & 0.2 & 25 & 20 & 17 & 0 & 2400 & 1626 & 1062 & 707 & 592 \\
\hline & Rooftop PV & 0.2 & 25 & 20 & 20 & 0 & 2840 & 1974 & 1364 & 947 & 791 \\
\hline South Africa & Utility-scale PV & 0.2 & 25 & 20 & 17 & 0 & 2400 & 1625 & 1062 & 707 & 592 \\
\hline & Rooftop PV & 0.2 & 25 & 20 & 20 & 0 & 2840 & 1974 & 1364 & 947 & 791 \\
\hline Rest of southern Africa & Utility-scale PV & 0.2 & 25 & 20 & 17 & 0 & 2400 & 1626 & 1062 & 707 & 592 \\
\hline & Rooftop PV & 0.2 & 25 & 20 & 20 & 0 & 2840 & 1974 & 1364 & 947 & 791 \\
\hline Brazil & Utility-scale PV & 0.2 & 25 & 20 & 17 & 0 & 1980 & 1567 & 1042 & 707 & 592 \\
\hline & Rooftop PV & 0.2 & 25 & 20 & 20 & 0 & 2680 & 2092 & 1408 & 947 & 791 \\
\hline Mexico & Utility-scale PV & 0.2 & 25 & 20 & 17 & 0 & 1980 & 1567 & 1042 & 707 & 592 \\
\hline & Rooftop PV & 0.2 & 25 & 20 & 20 & 0 & 2680 & 2092 & 1408 & 947 & 791 \\
\hline Rest of Central America & Utility-scale PV & 0.2 & 25 & 20 & 17 & 0 & 1980 & 1567 & 1042 & 707 & 592 \\
\hline & Rooftop PV & 0.2 & 25 & 20 & 20 & 0 & 2680 & 2092 & 1408 & 947 & 791 \\
\hline Rest of South America & Utility-scale PV & 0.2 & 25 & 20 & 17 & 0 & 1980 & 1567 & 1042 & 707 & 592 \\
\hline & Rooftop PV & 0.2 & 25 & 20 & 20 & 0 & 2680 & 2092 & 1408 & 947 & 791 \\
\hline
\end{tabular}

Table A5

Parameter change for sensitivity analysis on the economic potential $(<0.15 \$$ $\mathrm{kWh}^{-1}$ ).

\begin{tabular}{|c|c|c|c|c|c|}
\hline & - & - & Default & + & ++ \\
\hline Interest rate $(\%)$ & $5 \%$ & $7.5 \%$ & $10 \%$ & $12.5 \%$ & $15 \%$ \\
\hline Floor to roof area Betas ${ }^{1}$ & $0.8 \times$ & $0.9 \times$ & $1 \times$ & $1.1 \times$ & $1.2 \times$ \\
\hline Architectural suitable factor & 0.1 & 0.2 & 0.32 & 0.4 & 0.5 \\
\hline Capital cost Rooftop PV $\left(\$ \mathrm{~kW}^{-1}\right)$ & $0.25 \times$ & $0.5 \times$ & $1 \times$ & $1.25 \times$ & $1.5 \times$ \\
\hline Solar Irradiance $\left(\mathrm{kWh} \mathrm{m}^{-2}\right.$ day $\left.^{-1}\right)$ & $0.8 \times$ & $0.9 \times$ & $1 \times$ & $1.1 \times$ & $1.2 \times$ \\
\hline Performance ratio (\%) & $75 \%$ & $80 \%$ & $85 \%$ & $90 \%$ & $95 \%$ \\
\hline
\end{tabular}

1 The floor area to roof space conversion betas have been limited to the range of $0-1$ to prevent situations of negative roof surface area or roof areas higher than floor space.
Table A6

Parameter change for sensitivity analysis on the scenario analysis (rooftop PV production (TWh $\mathrm{y}^{-1}$ ) in 2030).

\begin{tabular}{llllll}
\hline & - & - & Default & + & ++ \\
\hline Cost Curve & $0.5 \times$ & $0.75 \times$ & $1 \times$ & $1.25 \times$ & $1.5 \times$ \\
Whole-sale electricity price & $0.5 \times$ & $0.75 \times$ & $1 \times$ & $1.25 \times$ & $1.5 \times$ \\
Electricity system integration cost & $0.5 \times$ & $0.75 \times$ & $1 \times$ & $1.25 \times$ & $1.5 \times$ \\
Rooftop PV potential & $0.5 \times$ & $0.75 \times$ & $1 \times$ & $1.25 \times$ & $1.5 \times$ \\
Rooftop PV capital cost & $0.5 \times$ & $0.75 \times$ & $1 \times$ & $1.25 \times$ & $1.5 \times$ \\
\hline
\end{tabular}




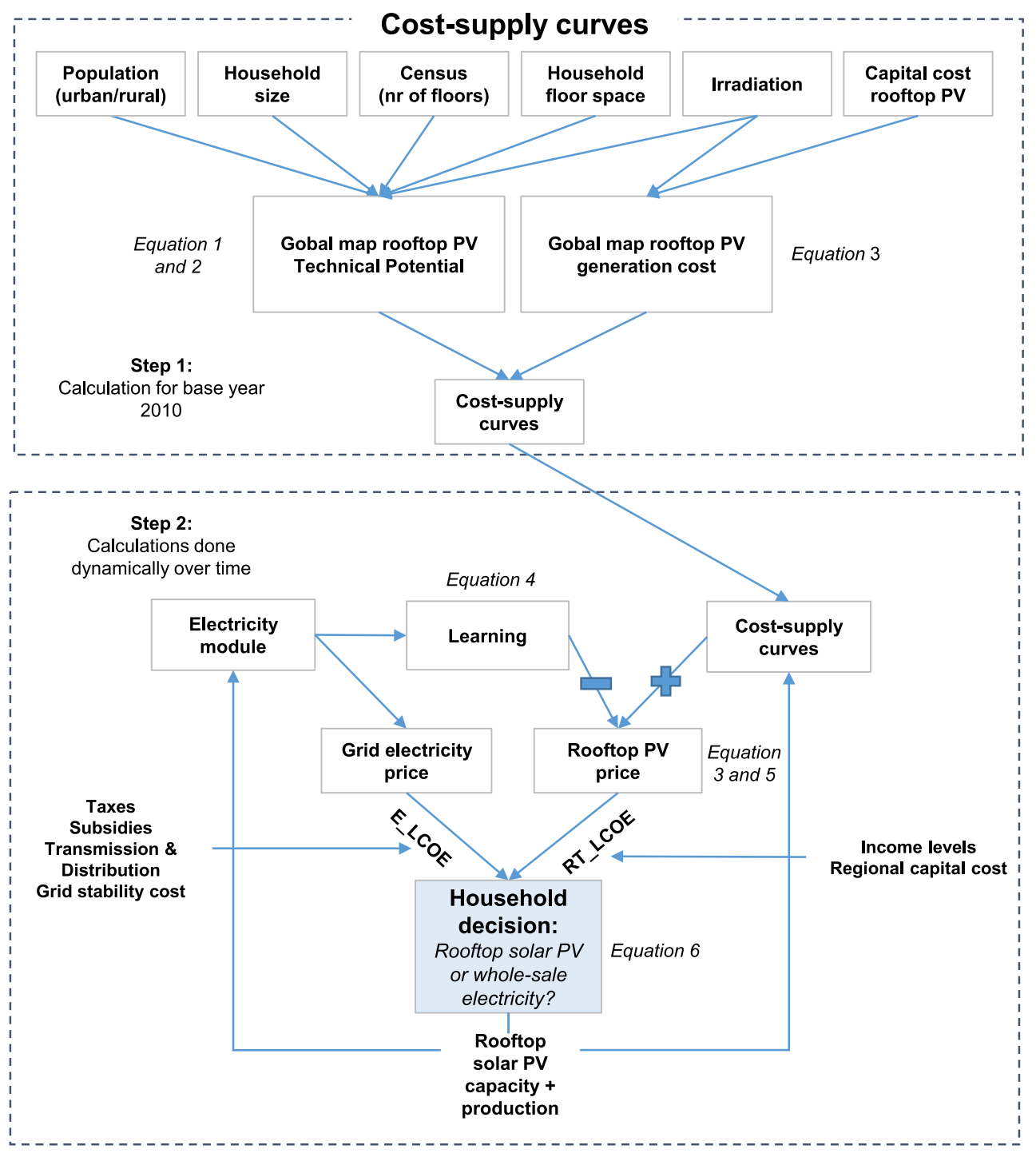

Fig. A1. Flow chart of the overall methodology. 
The 26 world regions in IMAGE 3.0

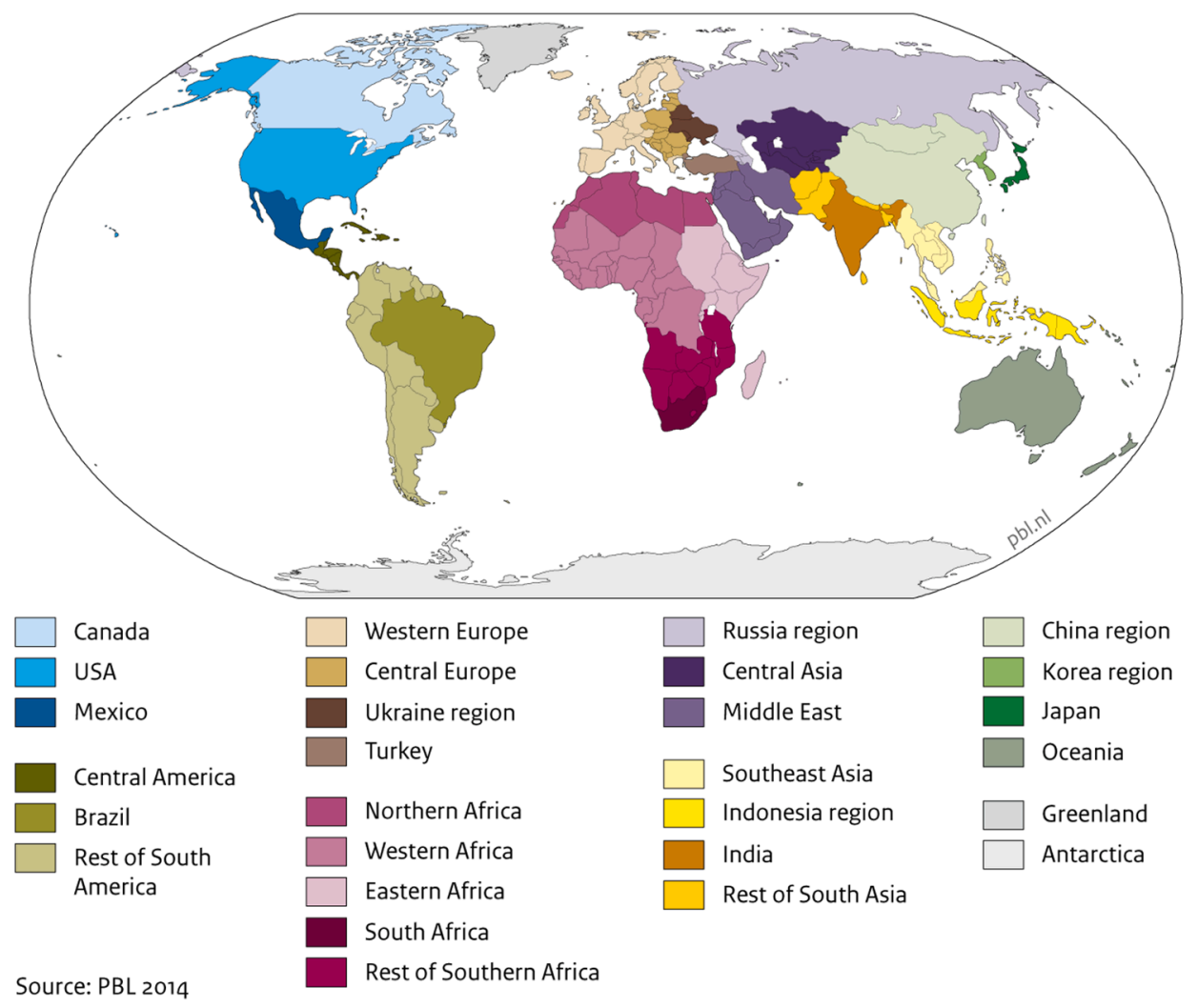

Fig. A2. Region definitions used in IMAGE. 


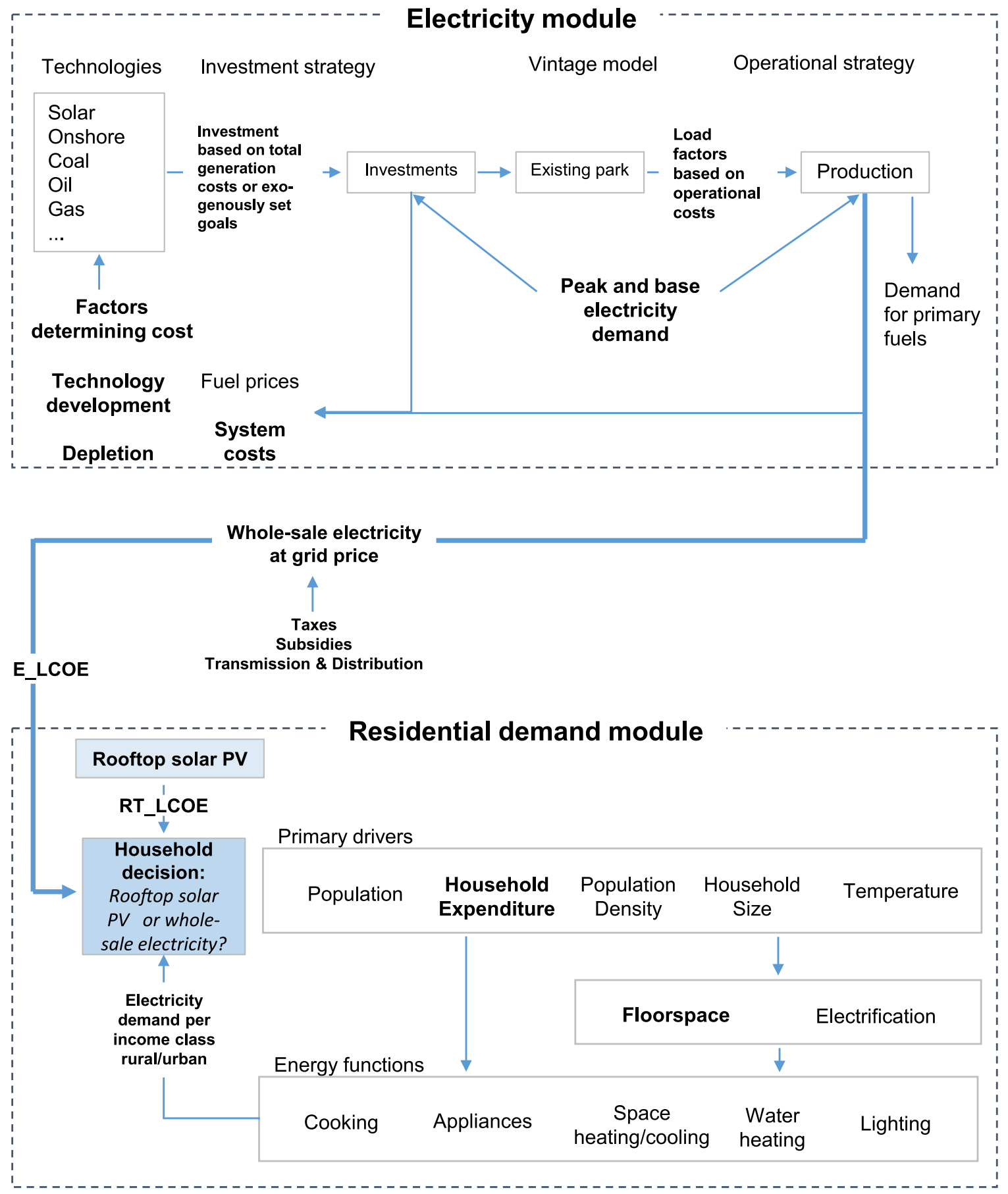

Fig. A3. More complex representation of Fig. 1 (main text) on modelling rooftop PV. See van Vuuren [65] and [26] for details on the electricity module. Daioglou [15] for details on the residential module. 

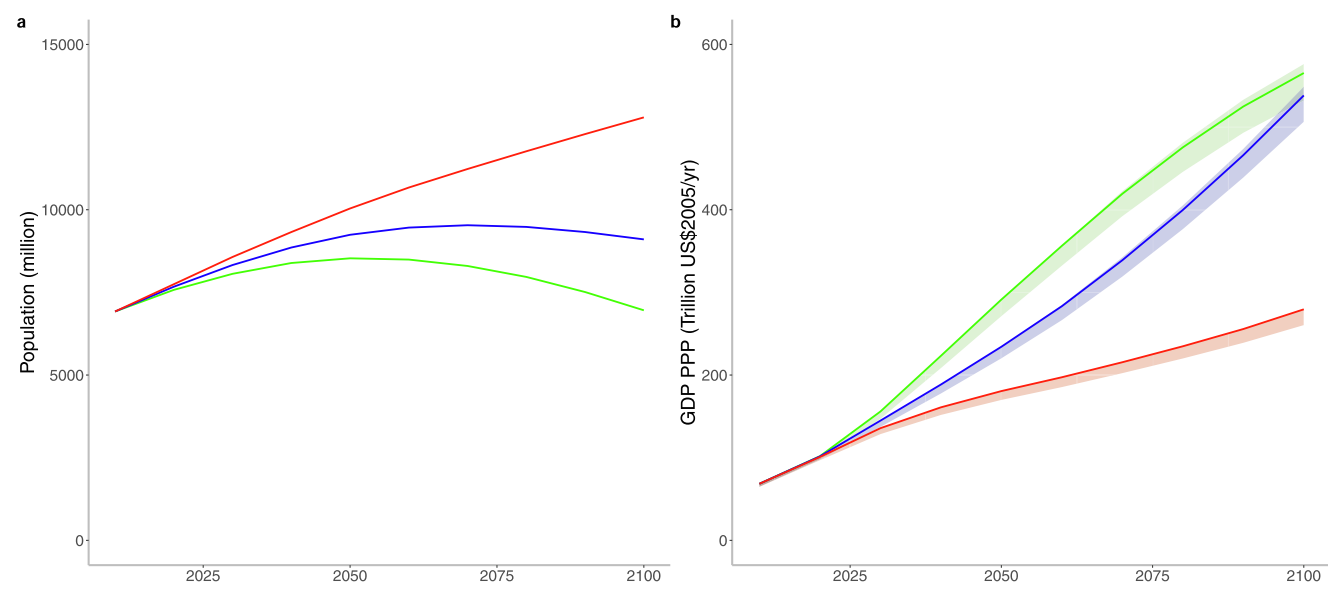

$-\mathrm{SSP} 1-\mathrm{SSP} 2-\mathrm{SSP} 3$

Fig. A4. Global population (left) and economic development (right). The shaded area indicates the range of results of the full set of IAM scenarios for the specific SSP. See Appendix, Text A2 for a detailed explanation of the SSP scenarios.
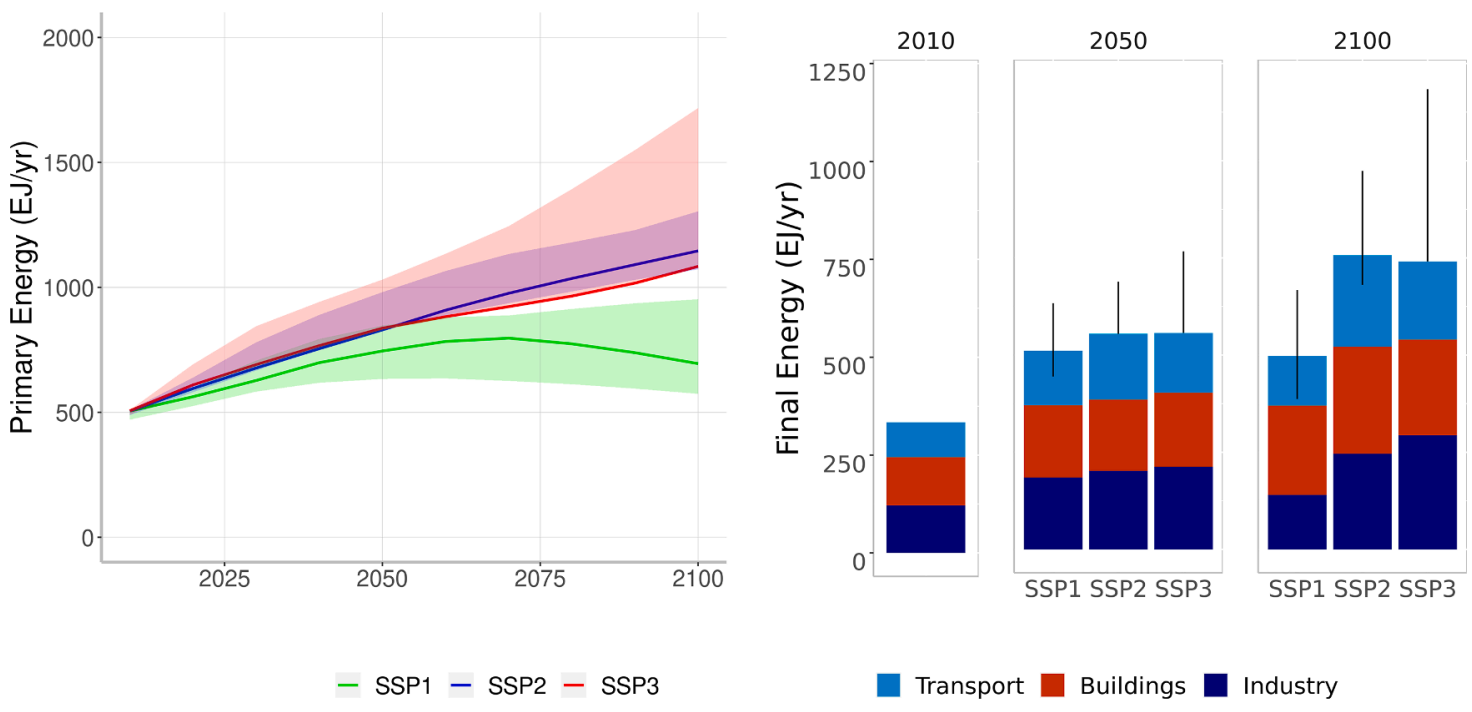

Fig. A5. Primary energy (left) and Final energy (right) development in SSP1, SSP2 and SSP3 scenarios. The shaded areas and the vertical lines indicate the range of results of the full set of IAM scenarios for the specific SSP scenario. See Appendix, Text A2 for a detailed explanation of the SSP scenarios.

renewable energies. Investments in education and investments in economic development lead to lower population levels and lower pressures on land. Combined with good governance, adaptation and mitigation to climate change under SSP1 are relatively easy. The SSP3 scenario describes a world of fragmentation; a world with low economic growth, slow technological development and high population growth. Here, both, adaptation and mitigation, are difficult. The SSP2 scenario indicates development pathways under median assumptions(See Tables A1-A6 and Figs. A1-A5).

\section{References}

[1] GMO. Global Market Outlook for Solar Power 2019 - 2023. In: Schmela M, editor. SolarPower Europe; 2019.

[2] IRENA. Letting in the light. In: Gielen D, Kempener R, Taylor M, Boshell F, Seleem A, editors. Internation Renewable Energy Agency; 2016.

[3] IEA-PVPS. Trends in photovoltaic applications 2019 Photovoltaic Power Systems Programme. IEA 2019.

[4] Paidipati J, Frantzis L, Sawyer H, Kurrasch A. Rooftop photovoltaics market penetration scenarios. Navigant Consulting Inc, for NREL; 2008.
[5] Lang T, Gloerfeld E, Girod B. Don' t just follow the sun-A global assessment of economic performance for residential building photovoltaics. Renew Sustain Energy Rev 2015;42:932-51.

[6] IRENA. IRENA Cost and Competitiveness Indicators: Rooftop Solar PV. Abu Dhabi: International Renewable Energy Agency; 2017.

[7] Seel J, Barbose GL, Wiser RH. An analysis of residential PV system price differences between the United States and Germany. Energy Policy 2014;69:216-26.

[8] IPCC-SRREN. IPCC Special Report on Renewable Energy Sources and Climate Change Mitigation: Hydropower. In: Kumar ATS, Ahenkorah A, Caceres-Rodriguez R, Devernay JM, Freitas M, et al., editors. IPCC; 2011.

[9] IRENA. Renewable Energy Technologies: Cost Analysis Series. Volume 1: Power Sector - Hydropower; 2012.

[10] IEA. Technology Roadmap - Solar Photovoltaic Energy. Paris: International Energy Agency; 2014.

[11] Bauer N, Calvin K, Emmerling J, Fricko O, Fujimori S, Hilaire J, et al. Shared socioeconomic pathways of the energy sector-quantifying the narratives. Global Environ Change 2017;42:316-30.

[12] van Vuuren DP, Stehfest E, Gernaat DEHJ, Doelman JC, van den Berg M, Harmsen M, et al. Energy, land-use and greenhouse gas emissions trajectories under a green growth paradigm. Global Environ Change 2017;42:237-50.

[13] IRENA. Renewable Power Generation Costs in 2017. Abu Dhabi: International Renewable Energy Agency; 2018.

[14] Fraunhofer. Photovoltaics report. Fraunhofer Institute for Solar Energy Systems; 2018. 
[15] Daioglou V, van Ruijven BJ, van Vuuren DP. Model projections for household energy use in developing countries. Energy 2012;37:601-15.

[16] WorldBank. World Development Indicators. The World Bank 2009.

[17] Daioglou V. Residential energy use scenarios [Master thesis]. Utrecht: Utrecht University; 2010.

[18] Gagnon P, Margolis R, Melius J, Phillips C, Elmore R. Rooftop solar photovoltaic technical potential in the United States: A detailed assessment. National Renewable Energy Laboratory (NREl). Technical report; 2016.

[19] Klein-Goldewijk K, Beusen A, Doelman J, Stehfest E. Anthropogenic land use estimates for the Holocene-HYDE 3.2. Earth Syst Sci Data 2017;9:927-53.

[20] IEA. World Energy Outlook. Paris: International Energy Agency; 2019.

[21] REN21. Renewables 2017 Global Status Report. Paris: REN21 Secretariat; 2017.

[22] Nemet GF. Beyond the learning curve: factors influencing cost reductions in photovoltaics. Energy policy 2006;34:3218-32.

[23] Neij L. Cost development of future technologies for power generation - A study based on experience curves and complementary bottom-up assessments. Energy policy 2008;36:2200-11.

[24] Shum KL, Watanabe C. Towards a local learning (innovation) model of solar photovoltaic deployment. Energy Policy 2008;36:508-21.

[25] Stehfest E, van Vuuren DP, Kram T, Bouwman L, Alkemade R, Bakkenes M, et al Integrated Assessment of Global Environmental Change with IMAGE 3.0 - Model description and policy applications. PBL The Netherlands Environmental Assessment Agency; 2014.

[26] de Boer HS, van Vuuren DP. Representation of variable renewable energy sources in TIMER, an aggregated energy system simulation model. Energy Econ 2017;64: $600-11$.

[27] Reddy BS. Consumer discount rates and energy carrier choices in urban households. Int J Energy Res 1996;20:187-95.

[28] Train K. Discount rates in consumers' energy-related decisions: A review of the literature. Energy 1985;10:1243-53.

[29] van Ruijven BJ, van Vuuren DP, de Vries BJ, Isaac M, van der Sluijs JP, Lucas PL, et al. Model projections for household energy use in India. Energy Policy 2011;39: $7747-61$.

[30] Jewell J, McCollum D, Emmerling J, Bertram C, Gernaat DEHJ, Krey V, et al. Limited emission reductions from fuel subsidy removal except in energy-exporting regions. Nature 2018;554:229.

[31] Riahi K, van Vuuren DP, Kriegler E, Edmonds J, O'Neill BC, Fujimori S, et al. The shared socioeconomic pathways and their energy, land use, and greenhouse gas emissions implications: an overview. Global Environ Change 2016;42:153-68.

[32] PBL. Het potentieel van zonnestroom in de gebouwde omgeving van Nederland. In: Jasper Lemmens JvdB, Theo Bosma, Ruud van den Wijngaart, Bas van Bemmel, Robert Koelemeijer, editor. Den Haag: PBL - Planbureau voor de Leefomgeving \& DNV GL; 2014.

[33] Sark W. Opbrengst van zonnestroomsystemen in Nederland. Universiteit Utrecht; 2014.

[34] Hoogwijk MM. On the global and regional potential of renewable energy sources [PhD]. Universiteit Utrecht, Faculteit Scheikunde; 2004.

[35] Deng YY, Haigh M, Pouwels W, Ramaekers L, Brandsma R, Schimschar S, et al Quantifying a realistic, worldwide wind and solar electricity supply. Global Environ Change 2015;31:239-52.
[36] Defaix P, van Sark WGJHM, Worrell E, De Visser E. Technical potential for photovoltaics on buildings in the EU-27. Sol Energy 2012;86:2644-53.

[37] Izquierdo S, Rodrigues M, Fueyo N. A method for estimating the geographical distribution of the available roof surface area for large-scale photovoltaic energypotential evaluations. Sol Energy 2008;82:929-39.

[38] Assouline D, Mohajeri N, Scartezzini J-L. Quantifying rooftop photovoltaic solar energy potential: a machine learning approach. Sol Energy 2017;141:278-96.

[39] OECD/IEA. Annex H - Rooftop Solar PV Potential in Cities. Energy Technology Perspectives; 2016.

[40] Fraunhofer. Recent Facts about Photovoltaics in Germany. In: Wirth H, editor.; 2017.

[41] Drury E, Denholm P, Margolis R. Modeling the US rooftop photovoltaics market. Golden, CO (United States): National Renewable Energy Lab (NREL); 2010.

[42] O'Neill BC, Kriegler E, Ebi KL, Kemp-Benedict E, Riahi K, Rothman DS, et al. The roads ahead: narratives for shared socioeconomic pathways describing world futures in the 21st century. Global Environ Change 2017;42:169-80.

[43] Quatar Ministry of Development Planning and Statistics. Qatar 2010 Population and Housing Census; 2010.

[44] EIA. Residential Energy Consumtion survey data; 2009.

[45] Hungarian Central Statistical Office. Population census. Budapest, Hungary; 2011.

[46] Australian bureau of Statistics. Census of Population and housing; 2001.

[47] INSTAT. Census of population and housing. Institute of Statistics; 2011.

[48] Statistics of Japan (e-Stat). Housing and Land Survey; 2014.

[49] Department of Statistics Jordan. Population and Housing Census; 2004.

[50] StatisticsFinland. Buildings and Free-time Residences; 2014.

[51] Hellenic Statistical Authority. Population-Housing Census; 2010.

[52] Federal Statistical Office. Census building and housing; 2013.

[53] Český statistický úřad. Veřejná databáze ČSÚ - Housing stock; 2011.

[54] Central Informatics Organisation. Census building and housing; 2010.

[55] Turkish Statistical Housing Census. Population and Housing Censuses; 2011

[56] Central Statistics Office Mauritius. 2011 Housing Census. Port Louis; 2011.

[57] Central State Office for Statistics Germany. Germany - Census of Population, Occupation, Dwellings and Buildings 1971 - IPUMS Subset; 1971.

[58] Central State Office for Statistics Germany. Germany - Census of Population, Occupation, Dwellings and Buildings 1981 - IPUMS Subset; 1981.

[59] Central Bureau of Statistics Indonesia. Indonesia - Population Census 1990 - IPUMS Subset; 1990

[60] Central Bureau of Statistics Indonesia. Indonesia - Population Census 1995 - IPUMS Subset; 1995.

[61] National Statistical Committee of the Kyrgyz Republic. Kyrgyz Republic - Census of Population and Housing of the Kyrgyz Republic 2009 - IPUMS Subset; 2009.

[62] Instituto Nacional de Estadisticas (INE). Spain - Census of Population and Housing 1991 - IPUMS Subset; 1991.

[63] Instituto Nacional de Estadisticas (INE). Spain - Census of Population and Housing 2011 - IPUMS Subset; 2011.

[64] IEA. World Energy Outlook. Paris, France International Energy Agency; 2017.

[65] van Vuuren DP. Energy systems and climate policy-long-term scenarios for an uncertain future $[\mathrm{PhD}]$. Utrecht: Utrecht University; 2007. 